\title{
FОTO CINEMA

\section{La fotografía en la obra de Gustavo Doré durante su viaje a España}

\section{The photography in Gustavo Doré's work during his trip to Spain}

\author{
Juan Antonio Fernández Rivero \\ Colección Fernández Rivero de Fotografía Histórica, Málaga, España \\ jafrivero@telefonica.net
}

\section{Resumen:}

Gustavo Doré está considerado como uno de los grandes ilustradores universales. A lo largo de su vida realizó una obra muy extensa destacando especialmente los trabajos realizados para ilustrar la Biblia, el Quijote y la Divina Comedia. En 1862 emprende un viaje por España acompañado del hispanista Charles Davillier. Uno de sus objetivos fue inspirarse para la realización de su trabajo sobre el Quijote, pero como resultado del viaje se publican diversas entregas para la revista Le Tour du Monde, entre los años 1862 y 1873 y, finalmente, un libro, titulado L'Espagne, publicado en 1874. Pero lo que resulta sorprendente en esta obra, y no ha sido hasta ahora bien estudiado, es que Doré, cuyo trabajo se caracterizaba por una imaginación desbordante, empleará numerosas fotografías para la realización de entre el $15 \mathrm{y}$ el 20\% de los grabados que ilustraron la revista y el libro.

\begin{abstract}
:
Gustavo Doré is considered one of the great universal illustrators. Throughout his life he made a very extensive work highlighting especially the work done to illustrate the Bible, the Quixote and the Divine Comedy. In 1862 he embarked on a trip through Spain accompanied by hispanist Charles Davillier. One of his objectives was to be inspired to carry out his work on Don Quixote, but as a result of the trip, several deliveries were published for the magazine Le Tour du Monde, between 1862 and 1873 and, finally, a book, entitled L'Espagne, published in 1874. But what is surprising in this work, and has not been well studied so far, is that Doré, whose work was characterized by an overflow-wing imagination, used numerous photographs for the realization of between 15 and $20 \%$ of the engravings that illustrated the magazine and the book.
\end{abstract}

Palabras clave: fotografía; grabado; ilustración; dibujo; imagen e imprenta; imágenes fotográficas.

Keywords: Photography; Engraving; Illustration; Drawing; Image and Printing; Photography images. 


\section{Introducción}

La fotografía se presenta oficialmente en París en agosto de 1839 en sesión conjunta de la Academia de Ciencias y la de Bellas Artes. En ese acto Louis Arago, que había sido el gran impulsor del invento de Nicéphore Niépce y Louis Daguerre, y de la adquisición de la patente por el estado francés para regalarla al mundo, hace un encendido discurso en defensa del nuevo invento. En este discurso ya deja bien claro las enormes posibilidades de la fotografía a la hora de reproducir las obras de arte, incrementando así su divulgación, de documentar los trabajos que entonces se estaban llevando a cabo en Francia bajo la supervisión de la Comisión de Monumentos Históricos ${ }^{1}$ o de la reproducción de los jeroglíficos egipcios (Sougez, 1985, pp 57 -58). Con gran clarividencia Arago supo ver lo que realmente luego fue una clamorosa realidad, primero con el daguerrotipo y luego con las sucesivas técnicas que fueron llegando.

Desde el momento en que el daguerrotipo pasa de ser un experimento científico a un producto comercial, debido a varios factores técnicos, como la reducción de los precios de las cámaras y ópticas pero muy especialmente a la reducción del tiempo de exposición que permite la realización de retratos (aunque fuera con el inconveniente de una pose larga y difícil), el interés por el procedimiento se dispara y el público comienza a familiarizarse con aquellos retratos en miniatura que tenían un "parecido" muy superior a lo conocido hasta entonces. Nada podía competir con la fuerza, el realismo y la supuesta objetividad que ofrecía la fotografía, de manera que la profesión de pintor miniaturista, al menos en lo que respecta a los retratos, quedó prácticamente desaparecida (Sougez, 1985, pp 86-88).

Pero hubo otro colectivo que supo ver la gran utilidad que para su gremio suponía la fotografía: el de los editores. Ellos se dieron cuenta del gran poder que tenía la fotografía como representación de la realidad, por encima de cualquier otro medio, y tenían que aprovecharlo de algún modo. El problema

\footnotetext{
1 "Rapport de M. Arago sur le Daguerréotype, Lu a la séance de la Chambre des Députés le 3 juillet 1839 et a l'Académie des Sciences séance du 19 août”. París, Bachelier imprimeurlibraire, $1839, \quad$ pp. $27 \quad$ a $35 . \quad$ Disponible en: https://gallica.bnf.fr/ark:/12148/bpt6k1231630?rk=42918;4
} 
estaba en la manera de conseguir reproducir o estampar una fotografía en un libro de una forma barata, pero la técnica tardó varias décadas en resolverlo. El daguerrotipo era una pieza única, pero enseguida se impuso el sistema negativo/positivo que permitía obtener infinitas copias a partir de un solo negativo (al menos teóricamente). Sin embargo, las copias así obtenidas seguían teniendo un coste elevado para que el gran público pudiera beneficiarse de ellas. Sólo una capa muy reducida de la sociedad podía permitírselo, a pesar de lo cual se llegaron a editar muchos libros con fotografías pegadas en sus páginas. Al margen de algunos intentos previos poco prácticos la solución de traspasar fotografías a un medio impreso mediante procedimientos fotomecánicos no llegaría hasta la década de 1880 (Sougez, 1989, p. 82). Por ello los editores encontraron entretanto un procedimiento alternativo que consistía en la mera reproducción de la manera más fidedigna posible de las fotografías, mediante pantógrafos o calcos, a un dibujo a tinta o lápiz que luego a su vez se traspasaba a una piedra litográfica, a las planchas para aguatinta o aguafuerte, o a una madera de boj para ser tallada, procedimientos que resultaban más económicos que la fotografía, de esta forma la fotografía encontró un nuevo circuito para la difusión de sus imágenes (Riego, 2001, p. 329 a 331).

Quizás el primer ejemplo de la historia de este procedimiento sea el de las Excursions Daguerriennes, una serie de láminas realizadas mediante grabados al aguatinta, editadas por el óptico parisino Nöel Lerebours a partir de daguerrotipos tomados desde 1839 (Lerebours, 1840-1844). Las diferentes láminas se vendían por entregas para ser luego encuadernadas. Las estampas, de diversas partes del mundo, muchas de Europa, son de una incuestionable belleza y calidad. El álbum contiene dos láminas de Granada y una de Sevilla. Los daguerrotipos fueron copiados en planchas de cobre por el procedimiento del aguatinta, pero los dibujos fueron enriquecidos con los personajes, carruajes, animales y otros sujetos en movimiento que debieran estar en la escena pero que habían quedado ocultos por la cámara (Sougez, 1985, p. 90). Esta manera de proceder sentó las bases de lo que habría de ser la pauta a seguir en los trasvases de fotografías al medio impreso hasta la generalización de los procedimientos fotomecánicos. 
Además de libros y carpetas de láminas una gran parte del negocio editorial estaba en la publicación de periódicos y revistas. No es casualidad que sea este por tanto el momento en el que se incrementan notablemente las publicaciones periódicas ilustradas, nacidas mucho antes, pero que justo ahora comenzarán sus periodos de gloria. Entre ellos el Illustrated London News, nacido el 14 de mayo de 1842, será uno de los paradigmas del medio, a imitación del cual surgieron muchos otros. En España uno de los más populares será el Semanario Pintoresco Español surgido en 1836 pero que en 1857 se transforma en El Museo Universal que tiene ya un formato muy similar al londinense, y que utilizó fotografías de Charles Clifford para la realización de sus grabados ya desde febrero de 1857 (Riego, 2001, pp 223224). En 1869 será a su vez sustituido por La Ilustración Española y Americana, con Laurent a la cabeza entre los muchos fotógrafos que vieron su nombre y sus fotografías impresos entre sus páginas. Estas revistas, junto al Museo de las Familias (1843-1870), serán las más conocidas de la época en España (Riego, 2001)

Para la prensa era especialmente útil advertir al lector que sus grabados provenían de fotografías pues ésta llevaba implícita una carga de veracidad que convenía a sus intereses, como queda claramente reflejado en la rivalidad entre dos grupos editoriales con motivo del cubrimiento de la guerra de África en 1859. Para zanjar la polémica el editor Gaspar y Roig realiza el anuncio que considera definitivo: “... Los lectores de la obra pueden por tanto estar seguros de que los grabados que en ella aparezcan serán la reproducción exacta de la verdad, pues la fotografía es la verdad misma y nada superior a ella puede prometerse ni efectuarse...” (Fernández Rivero, 2004, 154-155). Debemos no obstante advertir que este "halo" de veracidad y realismo que acompañaba a la fotografía era tan fuerte que en muchas ocasiones se añadía la coletilla: "de fotografía”, aunque no fuera cierto. Y también ocurría el hecho inverso, a veces un dibujante corresponsal del periódico o revista remitía un trabajo como propio, cuando en realidad había sido copiado literalmente de una fotografía ${ }^{2}$.

\footnotetext{
${ }^{2}$ Como ejemplo citaremos el grabado representando la voladura del Cerro de San Telmo de
} 
Este doble uso de la fotografía, unas veces reconocida (falsa o verazmente) y silenciada en otras ocasiones, ha sido puesta también de manifiesto en un artículo de Francisco Alonso Martínez sobre uno de los más clásicos ejemplos del uso de imágenes fotográficas en una publicación española sobre descripción geográfica, artística y monumental: "Recuerdos y Bellezas de España”, de Francisco Javier Parcerisa (Alonso, 1999). Esta obra fue editada en 12 volúmenes entre 1839 y 1865, y el uso de la fotografía para la confección de muchos de sus grabados y litografías está demostrado (Alonso, 1999, p. 197)). Pero al margen de ello nos gustaría resaltar aquí que Parcerisa en 1856, en un anuncio en la prensa sobre su obra argumenta el uso de la fotografía para prestigiarla, pues estamos en unos momentos en que esa mención certificaba la calidad de la imagen (Alonso, 1999, p. 195). Sin embargo, en la década siguiente "el reconocimiento de las imágenes dibujadas del natural cobró nueva fuerza. Y los posibles originales fotográficos en los que se basaron algunas de ellas fueron silenciados para siempre" (Alonso, 1999, p. 197). Este es el momento y la situación que nos encontramos en el trabajo de Doré sobre España.

\section{Gustave Doré, breve biografía}

Doré nace en Estrasburgo en 1832 y muere en París en 1883, a la edad de 51 años. Con 5 años ya dibujaba caricaturas en los márgenes de sus cuadernos escolares, a los 13 años ya vio publicadas sus primeras obras en forma de litografías y a los 15 firma su primer contrato profesional trasladándose a París (Casado, 2013, pp 19-21). En la capital se integrará en círculos de intelectuales y artistas y conocerá a personajes como Théophile Gautier, Jean-Charles Davillier o el fotógrafo Nadar (Gaspard-Félix Tournachon), quien le retrató en 1855, con 23 años, y con quien llegaría a tener una gran amistad. Desde muy pronto se propuso la idea de ilustrar ediciones de las más grandes obras de la literatura universal siendo de hecho finalmente sus mejores trabajos las ediciones del Quijote, la Divina Comedia y la Biblia. En

Málaga, aparecido en "La Ilustración Española y Americana" de fecha 8/3/1880, a cuyo pie aparece: "Dibujos de nuestro corresponsal D. E. de la Cerda", cuando en nuestra colección disponemos de una fotografía con idéntica escena firmada por Joaquín Oses. 
1861, 1862, y 1871 visita España con el barón Davillier, quien ya había visitado el país en varias ocasiones (Sazatornil, 2016, pp 15-18).

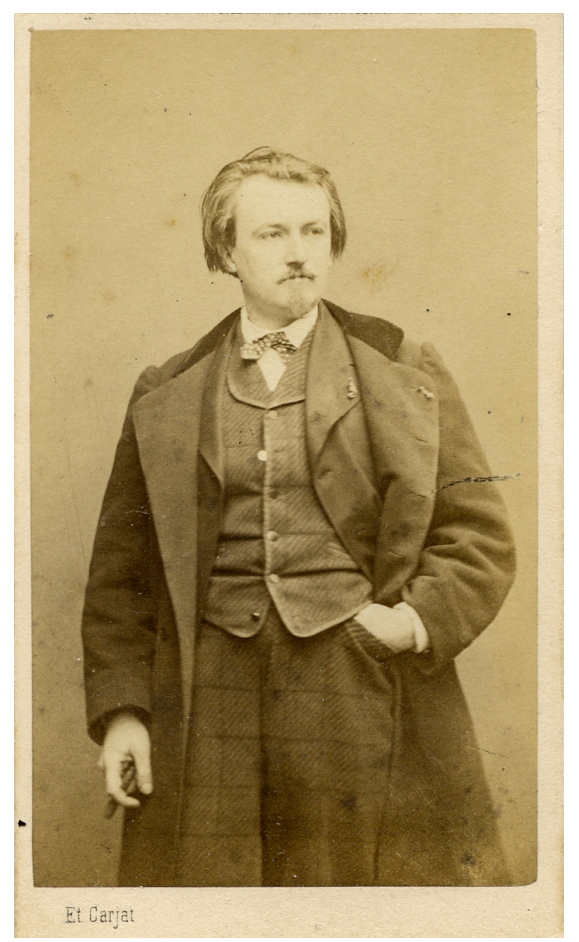

F1. Retrato de Gustave Doré por Étienne Carjat hacia 1862.

Durante las décadas de 1860 y 1870 trabaja frenéticamente ilustrando sobre todo obras literarias de grandes autores. Su maestría le permitió abordar cualquier forma de representación plástica: dibujo, pintura, escultura y acuarela, pero su gran anhelo era ser considerado un pintor más que un ilustrador, para lo cual realizó más de 200 pinturas que enviaba periódicamente a los "Salones”, aun sin éxito con la crítica. Su producción fue extensísima, más de 10.000 obras realizadas a lo largo de su vida activa. Trabajaba muchísimo pero también tenía colaboradores y a veces hasta 40 personas trabajando en su taller (Sazatornil, 2016, pp 16-17).

\subsection{Doré y sus métodos de dibujo}

Théophile Gautier, al que ya mencionamos como su protector, resumió muy bien el doble componente de la obra de Doré: “G. Doré es a la vez realista e 
imaginativo"3 citado por Kaenel, quien añade: "A sus ojos sin embargo son las cualidades de la imaginación las que prevalecen” (Kaenel, 2012, p. 3).

Durante la célebre visita de la reina Victoria de Inglaterra a París en 1855 Doré conoce al periodista Blanchard Jerrold, que está cubriendo el evento. Fruto de esta amistad Jerrold pide a Doré que ilustre un libro sobre Londres que él está preparando. Doré acepta y para documentarse debe vivir en la ciudad largos periodos de tiempo desde 1868. El libro, que finalmente se publica en 1872, fue un éxito de ventas y acabó abriéndole las puertas del mercado editorial inglés, pero no estuvo exento de críticas por la visión de Doré del Londres de los bajos fondos. Como ya dijimos no es un libro que pueda compararse con el realizado en España, pero lo que nos interesa de él son las anécdotas que Kaenel nos cuenta acerca de la preparación del trabajo. Doré recorre las calles acompañado de su amigo Jerrold y de dos dibujantes: Canon Hartford y Emile Bourdelein, que serán los encargados de realizar los levantamientos topográficos (y algunas veces también de protección policial), pero Doré hace poco dibujo de campo, prefiriendo preparar sus bocetos en casa a la vuelta. Cuando Jerrold le presiona para que dibuje sobre la marcha, Doré le responde una frase que se haría famosa: "Tengo la cabeza llena de colodión" 4 haciendo así alusión a su prodigiosa memoria fotográfica (Kaenel, 2012, pp. 1-4). A propósito de esta cualidad Kaenel cita también al crítico de arte inglés Philip Gilbert Hamerton quien en 1864 relata que Doré le contó cómo había descubierto una manera de diseccionar mentalmente un tema mediante la división y subdivisión del mismo, con el fin de volver a ponerlo todo en orden con sus detalles cuando él quisiera (1864, pp. 4-5). Mediante la práctica él había conseguido con este método llevar en su memoria una gran cantidad de imágenes e incluso había conseguido hacer una comprobación gracias a un amigo fotógrafo que tomó una fotografía de una catedral. Mientras su amigo revelaba la imagen él realizó su dibujo de memoria. Comparando luego los dos resultados se comprobó que al dibujo de Doré no le faltaba ningún detalle de importancia.

\footnotetext{
${ }^{3} \mathrm{G}$. Doré est à la fois réaliste et chimérique.

${ }^{4} \mathrm{~J}$ 'ai beaucoup de collodion dans la tête.
} 

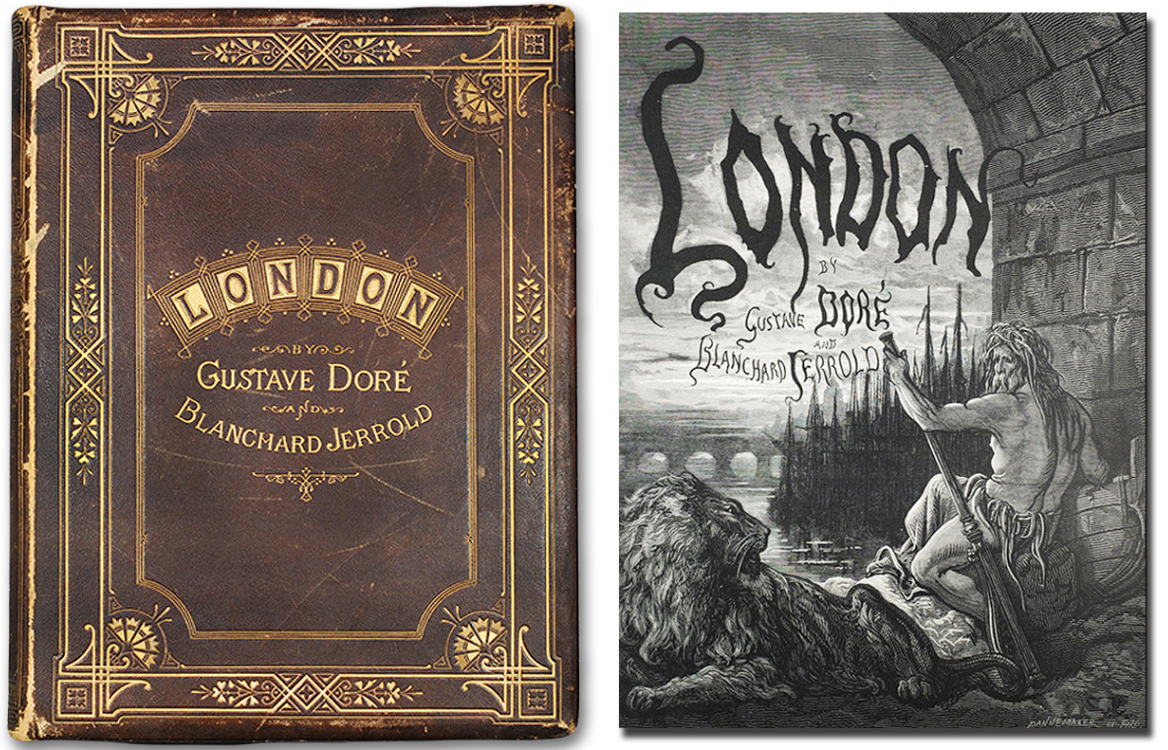

F2. Portada del libro London a pilgrimage, de Blanchard Jerrold.

Pero en Doré estará siempre presente esa dualidad entre ficción y realidad que ya apuntara Gautier. De este mismo autor traemos una nueva cita que también nos señala Kaenel:

A diferencia de muchos otros pintores, llenos de talento, él no copia nada; sus ideas son innatas, por usar un término filosófico; los encuentra en la naturaleza, pero no los extrae de ella (..) Todo es concebido y vivido previamente; el artista no abre la ventana para mirar el horizonte, ni consulta un estudio de follaje, ni ajusta un paño sobre un maniquí...5 (Kaenel, 2012, pp. 7-8).

En 1866 Emile Zola publica un curioso libro titulado: Mes haines (Mis odios). En él hay un capítulo dedicado a Doré con motivo de la reciente publicación de su Biblia ilustrada y en el que comienza alabando su facilidad de dibujo y su intuición, pero enseguida incide en la misma idea anterior, argumentando que las ideas fluyen de su cabeza: “... que el artista traza con mano rápida y calenturienta” o que:

\footnotetext{
${ }^{5}$ Différent de beaucoup d'autres peintres, pleins de talent, il en copie rien; ses idées sont innées, pour nous servir d'un terme philosophique; il les retrouve dans la nature, mains en les y puise pas (...) Chaque chose est conçue et vécue antérieurement; l'artiste n'a pas ouvert la fenêtre pour regarder l'horizon ni consulté une étude de feuillage, ni ajusté une draperie sur un mannequin....
} 
Ningún artista se curó nunca menos que él de la realidad. Doré ve solamente sus sueños; vive en un país ideal, cuyos enanos, cuyos gigantes, cuyo cielo esplendente y cuyos paisajes inmensos nos dibuja. Alójase en la fonda de las hadas, allá en la comarca del ensueño. Nuestro mundo le importa poco....

La crítica continúa de una forma despiadada para terminar afirmando: "Tal es la opinión de un realista acerca del idealista Gustavo Doré” (Zola, 1892, pp. 245-260).

Su desbordante imaginación es pues la principal característica del trabajo de Doré que sus coetáneos destacaron, tanto admiradores como detractores, de los que tuvo muchos a pesar del éxito comercial de sus obras editoriales.

Evidentemente estas opiniones cambiaron mucho con el tiempo, cuestión que no vamos ahora a abordar, pero sobre la que sí que viene a colación una nueva frase de Kaenel:

En el siglo XIX, tanto la ilustración como un medio como la fotografía, favorecieron la aparición de imágenes nuevas, puntos de vista inéditos, temas novedosos. La obra ilustrada de Doré está llena de imágenes que son pura invención visual, nunca antes vistas"6 (Kaenel, 2012, p. 15).

Esta nueva manera de mostrar las imágenes, que venían más de la imaginación que de la realidad, tiene mucho que ver con la aparición de la fotografía, algo que estaba ocurriendo también en la pintura y las otras formas de expresión figurativa.

Vemos por tanto que en Doré se daba esa doble cualidad de inventiva sin límites, con imágenes novedosas, al tiempo que poseía una prodigiosa memoria fotográfica capaz de reproducir hasta en sus últimos detalles varias imágenes o escenas captadas visualmente, quizás unas horas antes, durante un paseo por las calles de Londres. Pero si hay algo que define la obra de Doré es su especial atención a las personas, el elemento humano está presente en la gran mayoría de sus trabajos, hay muy pocos dibujos sin algún personaje. Otra cualidad que observamos enseguida en la gran mayoría de los dibujos de Doré es su alejamiento de la estética fotográfica, lo que cuadra

\footnotetext{
${ }^{6} \mathrm{Au}$ XIXème siècle, l'illustration ainsi qu'un médium comme la photographie ont favorisé l'apparition d'images nouvelles, de points de vue inédits, de thémes neufs. L'ouvre illustré de Doré regorge ainsi d'images qui sont de l'ordre de la purte invention visuelle, du jamais-vu.
} 
bien con su distanciamiento de la realidad que mencionaban Zola y otros contemporáneos. Su memoria "fotográfica” no tenía por qué servirle para reproducir una escena de la misma manera que lo hubiera hecho una fotografía, sino para interiorizarla y reinterpretarla. El hecho cierto es que cuando miramos cientos, o miles, de dibujos de Doré difícilmente podríamos pensar que alguno de ellos proviene de una fotografía. Quizás por ello nadie hasta ahora se ha detenido en analizar esta cuestión con cierta profundidad. Kaenel, del que hemos extraído interesante información acerca de Doré, habla mucho de la fotografía en relación con nuestro autor, pero nunca en el sentido que lo haremos nosotros.

Ya vimos al principio cómo el uso de la fotografía en la industria editorial era cosa común, especialmente en los años que nos ocupan (entre 1860 y 1890), pero el asunto no estuvo exento de polémica. Kaenel señala que el trabajo de Doré se desarrolla en un momento clave de las artes gráficas y que los intentos de transferir la fotografía a material impreso causaron muchos recelos, motivando incluso la agrupación de los profesionales que fundaron por ejemplo la Sociedad de Aguafortistas en 1862 para proteger sus intereses (Kaenel, 2012, p 4). Es en este contexto y en este momento cuando Davillier y Doré hacen su principal viaje a España, en 1862.

\section{Doré y su trabajo en España}

En 1857, su amigo y mentor Théophile Gautier describía a Doré como “monstruo del genio" (Sazatornil, 2016, p. 15). Con él realizó un viaje en 1855 por la costa vasca para ilustrar el libro Voyage aux eaux des Pyrénées, con textos de Hippolyte Taine (Taine, 1855). Es un libro que conoció muchas reediciones, la mayoría de ellas con el nombre adoptado en la edición de 1858: Voyage aux Pyrénées. Pero sería especialmente en los viajes de 1861 y 1862, con Davillier, cuando Doré realiza la mayor parte de sus recorridos por España. Tiene mucho interés en documentarse para preparar su libro sobre el Quijote y para ello insiste ante su amigo, que ya había estado varias veces en España, quien finalmente cede y le acompaña. De hecho, su libro cervantino aparece en 1863, con su nombre bien destacado en la portada, 
como ya era habitual en él. El viaje fue un encargo de la prestigiosa revista $L e$ Tour du Monde (Sazatornil, 2011, p. 361), que irá publicando en sus páginas los diferentes itinerarios, con textos y grabados, entre los años 1862 y 1873, hasta que finalmente queda todo recogido en una única publicación que con el título L'Espagne se publica en 1874 con 800 páginas y 309 ilustraciones (Davillier, 1874). A juzgar por el grabado que mencionaremos a continuación nos da la impresión que Doré pudo haber comenzado a realizar las ilustraciones para el Quijote antes de su viaje a España y constatando las dificultades que encontraba para documentarse correctamente hubiera apremiado a Davillier a emprender el viaje. Nos estamos refiriendo a una de las ilustraciones que aparece en la primera edición del Quijote de Doré, concretamente sobre el episodio de los molinos, y que reproducimos junto a otros grabados con molinos que aparecen respectivamente en las páginas 487 y 492 del libro L'Espagne. En el primero los molinos que aparecen nos recuerdan a los holandeses o franceses, motivo que nos lleva a plantear la hipótesis de que fueran realizados con anterioridad de su visita a España, mientras que en los segundos ya parecen molinos manchegos.
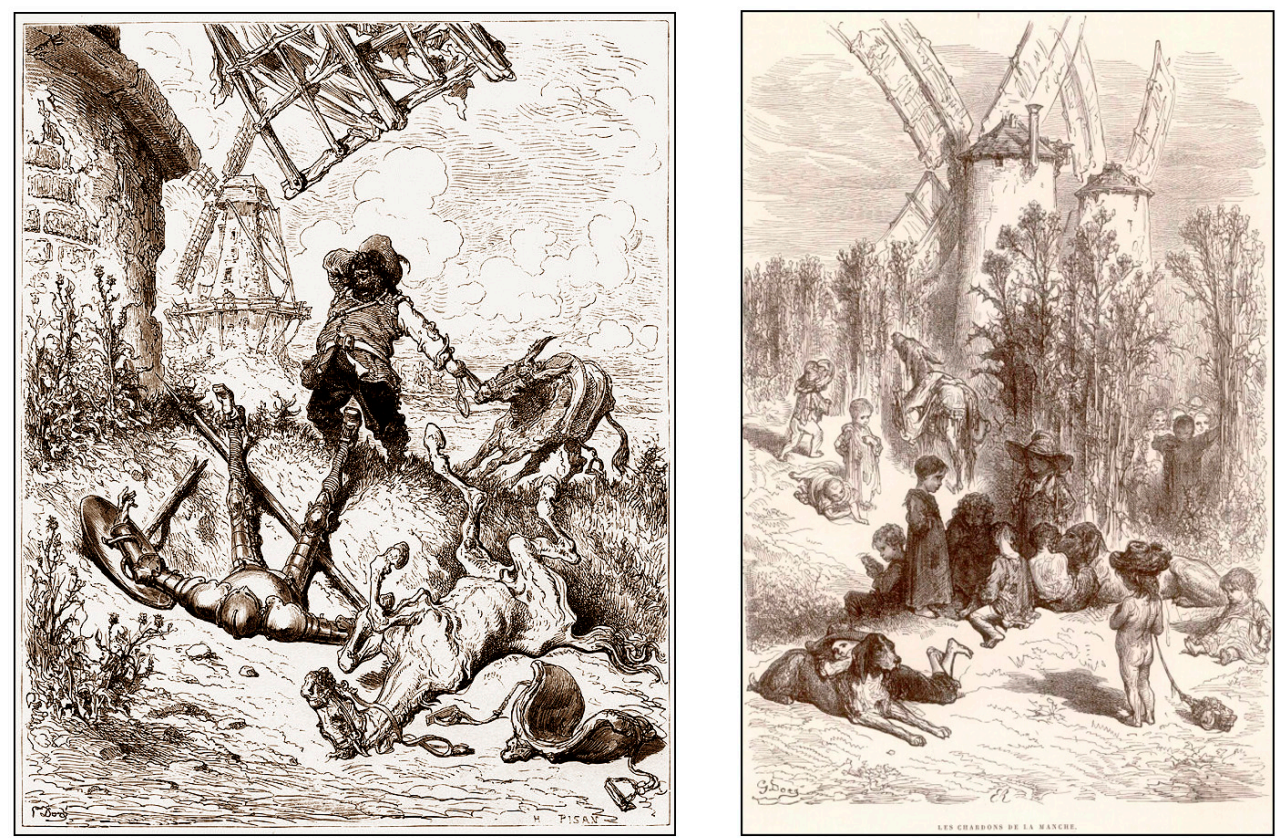

F3. Comparación de los dibujos de molinos manchegos en L'Espagne 


\subsection{Precedentes del uso de la fotografía por parte de Doré}

Los detalles y anécdotas del viaje a España con Davillier han sido ya abundantemente estudiados en numerosos artículos, por ello aquí solo nos centraremos en el aspecto que nos ocupa y que no es otro que la utilización por parte de Doré de fotografías de la época para la realización de algunos grabados que aparecen en su libro sobre España. Para abordar este estudio se han revisado los trabajos previos de Doré de corte similar al realizado en España, es decir libros de viajes ilustrados por Doré. Pero al examinar el conjunto de estas publicaciones buscando ejemplos del uso de la fotografía, solo encontramos uno que pudiera asemejársele, el ya mencionado realizado con Gautier y Taine en los Pirineos. Sin embargo, en este libro apenas encontramos ilustraciones del tipo que nos interesan, es decir ilustraciones que pudieran haber sido realizadas a partir de fotografías, al menos de corte similar a lo que luego veremos en el libro L'Espagne. Hay que tener en cuenta que el libro se publica en 1855, un momento en que la fotografía topográfica comercial está aún poco desarrollada. Sin embargo, para esas fechas ya estaban plenamente operativos en la zona algunos de los fotógrafos componentes de la llamada "Escuela de Pau", como Jean Jacques Heilmann cuya fotografía de la ciudad de Pau, con el río Gave en primer término y la ciudad con su castillo al fondo, nos recuerda mucho a uno de los grabados del libro. A este respecto encontramos más tarde dos citas interesantes que corroboraban nuestra primera impresión. Las dos figuran en la biografía de Doré que realizó William Blanchard Jerrold, periodista y escritor amigo de nuestro ilustrador, y persona que le conoció bien7. La primera dice lo siguiente:

Algunos de los más delicados y terminados estudios de paisajes de Doré se encuentran en el libro del señor H. Taine [Tour in the Pyrennes]. (...) La parte sorprendente de esta vívida obra de arte es que está inspirada en fotografías de los lugares representados ${ }^{8}$. (Jerrold, 1891, p 106).

\footnotetext{
${ }^{7}$ Jerrold murió en 1884, cuando estaba trabajando en la biografía de Doré, pero su trabajo fue finalmente publicado en Londres en 1891.

${ }^{8}$ Some of Dore's most delicate and finished pencil studies of scenery are to be found in M. H. Taine's book [Tour in the Pyrennes]. (...) The surprising part of this vivid art-work is, that it was inspired by photographs of the places represented.
} 
Y la segunda, citando a Taine:

Nunca hicimos un viaje a los Pirineos juntos. Cuando ilustró mi librito, no tenía nada más, creo, que fotografías del país. Fue M. Hachette quien nos unió, y quien actuó como medio plástico entre la pluma y el lápiz9

La afirmación no tiene por qué ser exacta pues ya sabemos que Doré sí viajó al País Vasco, pero de la mano de Gautier, por lo que es casi impensable que no realizara dibujos sobre el terreno. Lo que nos parece de cierto interés en la cita es la mención al editor Hachette que se ve jugaba un papel cercano y quien pudo haber tenido algo que ver con el uso de las fotografías para la edición. Son citas que nos sorprendieron mucho pues son prácticamente las únicas en que se menciona el uso de la fotografía por parte de Doré en todos los estudios sobre el ilustrador, antiguos y modernos, que hemos consultado.
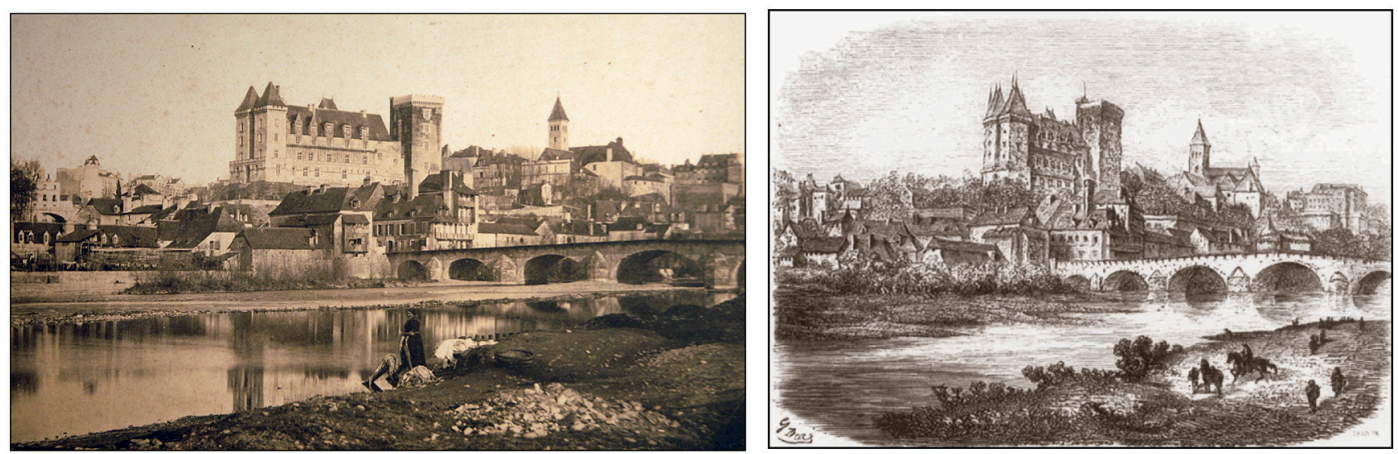

F4. Castillo de Pau. Comparación entre la fotografía de Heilmann y el grabado de la página 93 del libro Voyage aux eaux des Pyrénées, de H. Taine

A pesar de todo, esta publicación no nos sirve como referente para el trabajo que haría después Doré sobre España, pues apenas si podemos atisbar algún indicio de inspiración de algunos grabados a partir de fotografías, muy diferente al caso español, como veremos.

En una segunda etapa revisamos las publicaciones que Doré realizó con posterioridad a su trabajo sobre España, para buscar similitudes como las que nos interesan, sin encontrar ninguna que contuviese alguna coincidencia en el uso de las fotografías. La mencionada obra de Jerrold sobre Londres fue

\footnotetext{
${ }^{9}$ We never made a journey to the Pyrenees together. When he illustrated my little book he had nothing more, I believe, than photographs of the country. It was M. Hachette who brought us together, and who acted as the plastic medium between the pen and the pencil.
} 
en principio una candidata, pero tuvimos que desestimarla enseguida al no encontrar finalmente ningún atisbo o indicio del uso de la fotografía para la confección de sus grabados, en una obra por otro lado muy estudiada por autores ingleses y franceses. Estamos pues ante un trabajo muy singular en el conjunto de la obra de Doré, prácticamente sin parangón alguno en su obra anterior o posterior.

\section{2. Uso de la fotografía por Doré en su obra sobre España}

Ya hemos visto que Doré era tan capaz de llevar al límite su imaginación para reinterpretar las escenas de grandes obras literarias, como el Quijote o la Divina Comedia, como de recordar y reproducir con exactitud hasta los más mínimos detalles de cualquier escena real observada con anterioridad. Pero también que prefería el dibujo imaginativo a la reproducción exacta de la realidad (recordemos los ayudantes que llevó a Londres). Sin embargo, es evidente que no es lo mismo ilustrar la Biblia que un viaje a España. Lo que en este trabajo nos proponemos revelar es el uso de la fotografía para la confección de un buen número de grabados de su obra española.

$\mathrm{Su}$ amistad con Gautier y Davillier, reconocidos hispanistas, y especialmente su interés en completar de forma adecuada su Quijote, fueron las claves de su viaje a España. Una vez aquí sus preferencias se decantan decididamente por los personajes, mucho más que por la reproducción fiel y exacta de los monumentos. Se trata de un libro de viajes por España, financiado desde el principio por la revista Le Tour du Monde, cuyos responsables tenían que ofrecer a sus lectores imágenes fieles de los principales monumentos. Doré se decanta entonces por utilizar fotografías para la confección de buena parte de ellas. Su taller, compuesto por muchos empleados, podría encargarse de ello y el artista solo tendría que añadir algunos personajes.

La primera evidencia del uso de fotografías para la confección de los grabados nos la ofrece el propio Davillier. En su crónica para Le Tour du Monde relativa a Granada, podemos leer:

Uno de nuestros amigos, M. de Beaucorps, nos había recomendado a un viejo gitano llamado Ramírez, conocido por uno de los más ancianos, y de 
quien había tomado una fotografía muy exitosa que reproducimos ${ }^{10}$ (Davillier, 1864, pp 414 y 416).

Y bajo el grabado correspondiente dice, textualmente: "Un nevero de la Sierra Nevada - D'après une photographie de M. G. Beaucorps”.

Más tarde, en la publicación del libro con todas las crónicas de la revista, la frase del texto se repite idéntica, pero al pie del grabado ya solo aparece la parte en español, desapareciendo la mención al fotógrafo (Davillier, 1874, pp 220 y 222). Aunque el texto de Davillier no se modificó es evidente que Doré, o sus editores, no quisieron dejar al pie del grabado una mención tan evidente del uso de la fotografía. Lo mismo ocurrió luego en la edición inglesa.

A decir verdad y como quiera que la revista fue publicando las entregas desde 1862 hasta 1873, como ya dijimos, Doré pudo disponer de gran cantidad de fotografías españolas de autores muy variados, sin moverse de París, por ejemplo las realizadas por Gustave de Beaucorps que realizó un viaje por España tomando fotografías en 1858 y frecuentaba los mismos círculos parisinos que Davillier por lo que seguramente sus trabajos fueron conocidos por él y por Doré desde antes incluso de abandonar París. Quizás las que tuvieron mayor circulación fueron las estereoscópicas, de las que los fotógrafos y editores franceses publicaron varias colecciones entre los años 1856 y 1867 (Fernández Rivero, 2004). Las vistas de Ferrier, Alexis Gaudin et Frères, Ernest Lamy y Jean Andrieu fueron muy populares entre los franceses de aquellos años, pero también hay otros autores cuyas obras pudieron ser objeto de las miradas de Doré, además del mencionado Beaucorps. Fácilmente pudo tener a mano las vistas de Luis Leon Masson, Jean Laurent y Charles Clifford. Masson estaba representado en París por Durand-Ruel (Fernández Rivero y García Ballesteros, 2017, p. 55) y sus estereoscópicas figuraban en la colección de Furne \& Tournier (Fernández Rivero, 2004, p. 225). Respecto a Laurent, éste disponía ya desde 1868 de un establecimiento propio en París, en la rue Richelieu (Díaz Francés, 2016, pp.

\footnotetext{
${ }^{10}$ Un de nos amis, M. de Beaucorps, nous avait recommandé un vieux gitano nommé Ramirez, connu pour un des plus anciens, et dont il avait fait une photographie très-réussie que nous reproduisons.
} 
79-80). En cuanto a Clifford, aunque murió en enero de 1863, ese mismo año participaría de forma póstuma, junto a Masson, en una exposición en París, con positivos realizados por su esposa Jane (Fernández Rivero y García Ballesteros, 2017, p. 39), aunque seguramente sus trabajos se vendían ya en la capital francesa con anterioridad. Pero además Davillier y Doré pudieron examinar muchísimas fotografías en las propias ciudades visitadas pues era corriente que se vendieran en las principales librerías, tiendas de marcos y cuadros y en los propios establecimientos de los fotógrafos. Así debió ocurrir con Masson, Laurent y Clifford, y también con otros fotógrafos locales como Francisco de Leygonier en Sevilla o Charles Mauzaisse en Granada.

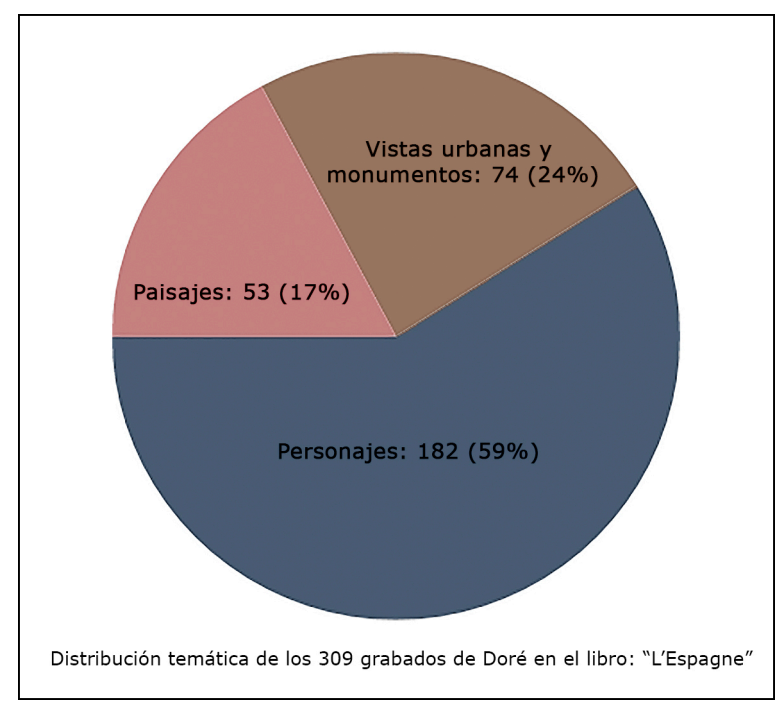

F5. Distribución temática de los 309 grabados de Doré en la obra: L'Espagne

\section{3•3 Clasificación de las ilustraciones de L'Espagne}

Para acometer nuestro estudio hemos clasificado las 309 ilustraciones que contiene L'Espagne en tres grupos: vistas urbanas y monumentos, paisajes y escenas con personajes. El resultado podemos verlo en la ilustración adjunta: alrededor del 60\% de los grabados tienen que ver con retratos y escenas en las que predominan las personas, y solo un 24\% pueden ser considerados como vistas urbanas, en total unos 74 grabados. Trabajaremos sólo con este grupo, pues en el resto no estimamos la posibilidad de que procedan de fotografías (a pesar de la excepción del gitano de Beaucorps), y a su vez lo reducimos a 66 descartando escenas urbanas que nos han parecido poco 
"fotográficas" o pertenecientes a lugares que no entraban en los circuitos fotográficos de la época.

Con esta selección hemos trabajado intentando encontrar imágenes fotográficas que pudiéramos relacionar con los correspondientes grabados. Debemos advertir que la realización de este estudio no ha sido fácil, por cuanto no existen muchos inventarios con imágenes fotográficas de la época disponibles para poder consultar y realizar el trabajo. No obstante, hemos de admitir que en los últimos años se han publicado varios trabajos que incluyen recopilaciones de fotografías de autores de la época, así como también en internet se han incrementado los repertorios fotográficos. Entre los libros con catalogación de obras mencionaremos el de Fontanella (1999) para Clifford, "El mundo al revés" (2015) para varios autores, y el de Fernández Rivero y García Ballesteros (2017) para Masson. Entre las fototecas virtuales hemos utilizado sobre todo la del IPCE para Laurent ${ }^{11}$. Pero también hemos trabajado con otras publicaciones y páginas web, así como con nuestra propia colección, especialmente para las fotografías estereoscópicas de las que de momento siguen sin existir colecciones de importancia disponibles para consulta.

Una cuestión importante a la que hemos prestado especial atención es la cronología, teniendo en cuenta las fechas de publicación de cada una de las entregas en Le Tour du Monde, examinando los diferentes recorridos realizados en cada uno de ellos y estudiando en cada caso las fotografías que se pudieron haber usado para la confección de los grabados. Es evidente que para la realización del trabajo Doré dispondría cómodamente en su taller de París de los apuntes realizados in situ y de las fotografías recopiladas en España y en el mismo París. Pero a pesar de que el viaje prácticamente finaliza en 1862, las entregas a Le Tour du Monde se extienden hasta 1873, de manera que Doré pudo disponer para cada entrega de las nuevas fotografías que en cada momento se fueran publicando, como así fue. 11 www.mcu.es/fototeca_patrimonio. Otra fototeca interesante es la del Museo de la
Universidad de Navarra (https://museo.unav.edu/coleccion/obras) 
En la magnífica recopilación de libros de viajes en España y Portugal de Foulché-Delbosc (1896, p. 250) encontramos una relación de los tomos y páginas de la revista en que aparecen las entregas de Davillier y Doré. Con estos datos y la posterior consulta de cada uno de los textos ${ }^{12}$, hemos elaborado un cuadro que adjuntamos. En total son 12 entregas repartidas entre los años 1862 y 1873, con las salvedades de que en el año 1864 se producen dos entregas y en 1870 ninguna. Finalmente, en 1874 se publica el libro L'Espagne con todos los textos e ilustraciones siguiendo el mismo orden que en la revista.

\begin{tabular}{|c|c|c|c|}
\hline \multicolumn{4}{|r|}{ Revista: LE TOUR DU MONDE } \\
\hline Año & Tomo & Páginas & Zonas o lugares visitados \\
\hline 1862 & II & 289-352 & Cataluña: Figueras, Gerona, Barcelona... \\
\hline 1863 & II & $353-368$ & Valencia, Alcoy \\
\hline 1864 & II & 1 a 32 & Orihuela, Albacete, Alicante, Elche \\
\hline 1864 & II & $356-416$ & Granada, Alhambra \\
\hline 1865 & II & $353-432$ & Jaén, Lanjarón, Ronda, Málaga, Jérez, Cádiz, Sevilla, Itálica \\
\hline 1866 & II & $353-416$ & Sevilla \\
\hline 1867 & II & $305-368$ & Bailes y cantes, tauromaquia, Córdoba, Despeñaperros, La Mancha \\
\hline 1868 & II & 289-352 & La Mancha, Toledo \\
\hline 1869 & II & $273-336$ & De Toledo a Madrid \\
\hline 1871 & II & $177-208$ & Madrid, El Escorial, Cuenca, La Granja, Segovia \\
\hline 1872 & II & $337-416$ & $\begin{array}{c}\text { Salamanca, Valladolid, Palencia, León, Galicia, Asturias, Burgos, } \\
\text { Zaragoza... }\end{array}$ \\
\hline 1873 & I & $369-400$ & País Vasco, Mallorca \\
\hline
\end{tabular}

F6. Años de edición de los capítulos de L'Espagne publicados en Le Tour du Monde

\subsection{Coincidencia de los grabados con fotografías}

Tras el examen de la selección de los 66 grabados mencionados hemos logrado relacionar 34 de ellos con fotografías concretas. En el Cuadro 1 (ver Anexo 1) se recogen todos ellos además de los tres mencionados de Bégin. De los 29 grabados restantes sospechamos, de algunos más que de otros, que también podrían haber tenido su origen en una fotografía, aunque por el momento no hayamos logrado identificarla. En el Cuadro 2 (ver Anexo 2) quedan relacionados. A continuación, comentaremos con más detalle cada uno de estos grupos.

12 Para la consulta de la revista Le Tour du Monde hemos utilizado sobre todo la web Gallica de la BNF, pero también algunos otros recursos online y ejemplares originales para los no disponibles en internet. 
En el Cuadro 1 tenemos en la primera columna la página en la que se ubica el grabado correspondiente, la ciudad o lugar que representa y el título original en francés del mismo. Para ello hemos utilizado la primera edición original del libro "L'Espagne”, por el barón Charles Davillier, ilustrado por Gustavo Doré y editado por Hachette en París en 1874. En la siguiente columna figura una reproducción del grabado y en las columnas siguientes la fotografía o fotografías que pudieron servir para su confección. En la última columna de cada fila figura el detalle de autoría de cada una de las fotografías, añadiendo, además, cuando ello ha sido posible, la numeración o referencia que pueda identificarla. En el caso de Clifford hemos usado la relación de Lee Fontanella (1999), en el de Masson la de Fernández Rivero y García Ballesteros (2017), en la de Laurent su propia numeración, así como en las estereoscópicas de Ferrier, Gaudin y Lamy. El resto de fotógrafos mencionados carecen de numeración propia o de estudios monográficos que cataloguen su obra. Para el caso de los grabados que se citan de Bégin hemos usado la página en que figuran los grabados correspondientes en la única edición existente del libro (Bégin, 1852).

Entre los grabados que figuran en el Cuadro 1 nos gustaría diferenciar 24 de ellos (los situados en las páginas: 154, 163, 171, 222, 223, 243, 299, 307, 317, $321,327,331,451,529,539,542,577,584,593,601,605,621,631$ y 635) que en nuestra opinión proceden de forma inequívoca de la fotografía o fotografías que figuran en el cuadro, luego estarían los tres que proceden de grabados del Bégin y por último de los diez restantes sospechamos que podrían proceder de las fotografías que figuran en el cuadro o de duplicados de placa o piezas fotográficas del autor señalado de las que no hemos logrado hallar una copia.

Como sabemos, cuando los grabadores usaban fotografías para la confección de su trabajo, añadían en los mismos los personajes, carruajes y en general elementos móviles que la fotografía no pudo captar de la escena original. Para ello se valían de los apuntes tomados sobre el terreno, de su memoria o bien de su propia imaginación. Pero lo extraordinario en el caso de Doré es el desproporcionado tamaño relativo de los personajes en relación con la dimensión real de las calles y monumentos, lo que evidentemente hacía de 
una forma consciente. Este sobredimensionamiento podía llegar a duplicar o triplicar el tamaño real. Con la fotografía en la mano el dibujante elegía un encuadre concreto de la misma, recortando la parte que más le interesara, por lo demás poca imaginación cabía añadir en motivos tan reales y contundentes como eran edificios y monumentos. La parte creativa era el elemento humano añadido y Doré no estaba dispuesto a que eso quedara empequeñecido en su dimensión real. Puede ser discutible en el plano estricto de la pura representación de la realidad, pero ese nunca fue el objetivo de Doré, como ya hemos visto, y por lo demás si consideramos una dimensión más artística y creativa el resultado es sin duda más interesante que si hubiera respetado la escala real. Otra característica que hemos observado en los grabados de Doré es su predilección por los formatos verticales, la razón de ello podríamos encontrarla en que la mayor parte de su trabajo iba destinado a la ilustración de libros. En la selección de 66 grabados que mencionamos anteriormente solo algo menos de un tercio son horizontales.

Con la salvedad de los elementos humanos añadidos debemos decir que al menos para el grupo de los veinticuatro grabados que hemos relacionado con fotografías de una forma más veraz encontramos el grabado de una gran fidelidad respecto a la fotografía, prácticamente sin cambio alguno en la perspectiva o las sombras, viéndose afectados solamente, y no en todos los casos, por un determinado recorte de la fotografía original.

\subsection{Fotógrafos/editores presentes en la obra de Doré}

En cuanto a los fotógrafos y editores que figuran en la ilustración F7, hay que destacar que ninguno de ellos es español, abundando los franceses, algo lógico, no sólo por ser de la misma lengua que Davillier y Doré, sino porque fueron en realidad los que más viajaron a la península, muy por encima de los ingleses, de los cuales sólo tenemos a Clifford y Robert P. Napper, quedando por fin el italiano Alejandro Massari. Luego observamos que destaca sin duda la figura de Laurent, lo que en principio resulta algo sorprendente pues él realmente no comenzó a tener un gran catálogo español hasta finales de la década de 1860, pero en lo que respecta a Madrid y 
alrededores, lugares menos trabajados por sus colegas franceses, muy interesados en las ciudades andaluzas, sí que dispuso de numerosas vistas desde inicios de la década. De Laurent hemos querido incluir su fotografía $\mathrm{n}^{0}$ 243 por su similitud con el grabado $n^{0} 193$, que nos muestra una triple arcada delante de la alberca del Generalife, aunque sabemos que la fotografía ha sido datada en fecha posterior al grabado (Piñar, 2013, p. 221). En cambio, la fotografía de la puerta del Perdón de la Mezquita de Córdoba, $n^{0}$ 313, figuraba ya en el catálogo de Laurent de 1867 (Montes, 1999, p. 42) y muy bien pudo ser usada para el grabado del aldabón de la puerta que figura en la página 449. De Toledo hemos incluido también el grabado de la página 524, que nos muestra el pozo del patio del convento de San Pedro Mártir, por guardar cierta relación con la placa número 12 de Laurent, que mostramos en sus versiones estereoscópicas y tamaño álbum.

\begin{tabular}{|c|c|c|}
\hline Fotógrafos / Editores & $\begin{array}{c}\text { Periodos de actividad en } \\
\text { España }\end{array}$ & $\begin{array}{c}\mathbf{N}^{\mathbf{o}} \text { de grabados } \\
\text { relacionados }\end{array}$ \\
\hline Alphonse Delaunay & $1851-1854$ & $1 / 2$ \\
\hline Francisco de Leygonier & $1851-1875$ & 3 \\
\hline Charles Clifford & $1852-1863$ & $1 / 2$ \\
\hline Alejandro Massari & $1853-1872$ & 1 \\
\hline A. Gaudin & 1857 & 2 \\
\hline Ferrier, pére, fils et Soulier & 1857 & 1 \\
\hline Gustave de Beaucorps & 1858 & 3 \\
\hline Luis Leon Masson & $1858-1865$ & $3 / 6$ \\
\hline Charles Mauzaisse & $1858-1885$ & $2 / 3$ \\
\hline Jean Laurent & $1858-1886$ & 1 \\
\hline Louis de Clercq & 1860 & 1 \\
\hline Robert P. Napper & $1862-1863$ & 4 \\
\hline Ernest Lamy & 1863 & \\
\hline
\end{tabular}

F7. Fotógrafos relacionados con los grabados de Doré

Pero donde encontramos fotografías de Laurent usadas sin duda para la confección de nuestros grabados es en Madrid. La primera de ellas es la que relacionamos con el grabado número 577, estatua de Felipe IV en la plaza de 
Oriente, aunque también la fotografía estereoscópica n 6405 de Ferrier guarda un gran parecido. En cambio, los grabados de las páginas 584 (Cibeles), 593 (Fuente de las Cuatro Estaciones en el Prado), 601 (Palacio Real), y 605 (Armería), coinciden plenamente con las respectivas fotografías de Laurent hasta sus últimos detalles y lo mismo cabría decir de los grabados de El Escorial ( $n^{\circ}$ 621) y La Granja ( $n^{\circ}$ 631). De la vista general del monasterio de El Escorial ( $n^{\circ}$ 617) solo hemos encontrado una fotografía de Laurent bastante similar pero no idéntica.

Entre los estereoscopistas franceses destacan en nuestra relación Gaudin y Lamy. Del primero, que disponía de un extenso catálogo, tenemos su fotografía $\mathrm{n}^{0} 229$ con una perspectiva de la fábrica de tabacos de Sevilla, que es idéntica al grabado de la página 331 del libro, así como la $n^{0} 150$, de Segovia, que, un poco recortada, es exacta al grabado de la página 635. De Ernest Lamy, que realizó su colección en 1863 y fue probablemente la más circulada en los momentos en que Doré preparó sus publicaciones, encontramos cuatro casos igualmente incontestables y uno más dudoso del que hablaremos luego. El grabado de la página 243 es el único que hemos seleccionado de Málaga, se trata de una vista del muelle en el puerto y la catedral al fondo que se corresponde perfectamente con el número 93 de la colección estereoscópica de Lamy, (hay cierta controversia de autoría entre Ernest Lamy y José Spreáfico con las fotografías malagueñas, que puede verse en Fernández Rivero (2011). En este caso puede compararse muy bien el tamaño real de los personajes que aparecen en la fotografía con los que vemos en el grabado, como siempre en Doré, de un tamaño exagerado. La Puerta del Perdón de la catedral sevillana que tenemos en la página 307, es una vista muy forzada desde el frente de la calle que está sin ninguna duda realizada a partir del $n^{0} 43$ de Lamy. La fotografía $n^{0} 23$ de la puerta de Bisagra de Toledo sirvió de modelo para el grabado de la página 542. Por último, tenemos el curioso caso del grabado de la página 223 que supuestamente representa la ciudad de Lanjarón y que en realidad es una 
fotografía de Alicante tomada de la estereoscopia ${ }^{0} 98$ de la colección de Lamy, sin duda un error no intencionado ${ }^{13}$.

De Luis Masson hemos incluido fotografías que parecen inspiradoras de algunos grabados (volvemos a repetir que estas similitudes pueden esconder copias fotográficas no halladas aún) pero también otras cuyo uso por parte de Doré o sus ayudantes no ofrece lugar a dudas. Entre las primeras tenemos las que acompañan a los grabados de las páginas 187 (triple arcada en la Alhambra), 325 (patio del palacio de San Telmo) y 443 (interior de la mezquita de Córdoba), y entre las segundas estarían las que hemos relacionado con los grabados números 451, con la portada del antiguo hospital de San Sebastián de Córdoba, caso éste muy curioso por cuanto en la fotografía queda cortada la parte de arriba de la decoración de la puerta, con lo que Doré se ve obligado a realizar el mismo recorte, y el número 539 con una vista del claustro de San Juan de los Reyes que ha sido calcado de la correspondiente fotografía recortando un poco por los laterales. Masson pudo haber sido contactado en la misma Sevilla, durante el viaje, o bien sus fotografías pudieron ser obtenidas en París a través de su representante ya mencionado.

Charles Clifford era el fotógrafo que disponía del mejor catálogo comercial de vistas españolas en aquellos momentos, pero por alguna razón, quizás por su prematura muerte en enero de 1863 , no fueron sus obras las más utilizadas por Doré y sus ayudantes. Tras una concienzuda búsqueda solo hemos podido relacionar dos de sus trabajos con los grabados del libro, ambas de Toledo. El caso del grabado que figura en la página 517 (Puerta del Sol) es peculiar por cuanto el dibujo parece contener una cierta incoherencia pues por más que lo observamos detenidamente no logramos comprender la extraña perspectiva del lienzo de muralla que figura a la derecha con respecto al resto del dibujo. Posiblemente el dibujante interpretó mal el juego de luces y sombras de la fotografía utilizada. De esta puerta existen muchos ejemplos fotográficos de la época, el propio Clifford tiene varias, pero la que hemos escogido es la $\mathrm{n}^{0} 616$, aunque no nos hemos resistido a añadir también la

${ }^{13}$ Comunicación personal de Javier Piñar y Carlos Sánchez. 
fotografía estereoscópica $n^{0} 22$ de Lamy. Ninguna de las dos parece haber sido la fuente exacta del grabado. En cambio, la fotografía $n^{0} 610$ en la que Clifford nos muestra el interior del Alcázar de Toledo sí que resulta ser idéntica al grabado ${ }^{0} 529$.

De Beaucorps, de quien ya aludimos a su amistad con Davillier y Doré y el uso de una de sus fotografías, tenemos el grabado número 222, que nos muestra al gitano Ramírez "reconvertido" en nevero. En la única fotografía que conocemos de ese mismo personaje (en el Museo de Orsay, en París) aparece con una guitarra en la mano, pero Doré nos lo muestra con un trabuco para su mejor caracterización en el papel que le adjudicó. No sabemos si pudo disponer de alguna otra copia en la que el personaje presentara una postura diferente, (muy posible dada la dispersión e incompleta recopilación de la obra española de Beaucorps) o simplemente recompuso su dibujo. El grabado $n^{0} 175$ representa una galería lateral del Patio de los Arrayanes al que hemos encontrado relación con una fotografía de Beaucorps y también con otra de Leygonier. Pero el $n^{0} 299$, con la fachada del ayuntamiento de Sevilla, parece ser una reproducción exacta de la fotografía de Beaucorps que acompañamos en el cuadro.

De Francisco de Leygonier, sevillano de ascendencia francesa y pionero de la fotografía en aquella ciudad, donde posiblemente contactó con Doré y Davillier, hemos seleccionado, además de la mencionada en el párrafo anterior, dos fotografías que a nuestro parecer fueron sin duda utilizadas para la confección de los respectivos grabados sevillanos números 317 y 321 con la portada y arquerías del Alcázar hispalense. De gran fidelidad es también la relación entre el grabado de la página 327, fachada de La Caridad en Sevilla, y la fotografía que hemos atribuido a Alejandro Massari.

Otro fotógrafo local es el francés establecido en Granada Charles Mauzaisse, quien realizó una amplia colección de fotografías granadinas. El grabado de la página 154 que titulan en el libro: "Porte de la Torre de las Infantas”, está realizado a partir de una fotografía de Mauzaisse de una de las maquetas en yeso de la época y no se corresponde con exactitud con ninguna puerta real, lo que probablemente desconocían los autores del libro a la hora de incluirla. 
Aquí es muy notorio el incremento desproporcionado del tamaño del personaje en relación con las medidas habituales de las puertas de la Alhambra. El siguiente grabado, en la página 163, nos muestra el Mirador de Lindaraja con dos personajes, y está tomado de otra fotografía de Mauzaisse. En el libro este grabado aparece recortado por la parte superior, pero en la entrega de la revista Le Tour du Monde está completo. Y aquí se da una curiosa circunstancia y es que la copia positiva de la fotografía tiene una mancha negra en su parte inferior izquierda, procedente de un defecto de la placa, pero el grabador lo confunde y acaba dibujando una especie de saliente decorativo en el zócalo, que por supuesto no existe en la pared original, lo que demuestra de una forma inequívoca la procedencia del grabado ${ }^{14}$.

Alphonse Delaunay y Louis De Clercq fueron dos de los discípulos de Gustave Le Gray que practicaron su sistema del negativo de papel encerado. No fueron fotógrafos comerciales, como la mayoría de los mencionados anteriormente y por tanto su trabajo debió estar mucho menos accesible, pero quizás Beaucorps, discípulo también de Le Gray, pudo servir de conexión entre ellos. Del primero hemos seleccionado una fotografía, que muestra el Patio de los Arrayanes de la Alhambra enmarcado tras un arco decorado, para relacionarla con el grabado $n^{0}$ 171. Ambas imágenes tienen muchas similitudes en su composición y perspectiva, pero en la parte superior encontramos algunas diferencias que sin embargo no lo son tanto en la fotografía de Charles Mauzaisse que relacionamos también con este grabado. En casos como este no creemos que Doré utilizara una combinación de ambas para realizar el dibujo sino más bien que trabajara con alguna variante (duplicados de placa) de cualquiera de las dos y de la que no hemos logrado hallar una copia. En la página 187 tenemos un pequeño grabadito, sin título, de una puerta en la Alhambra, que nos lleva también a una fotografía de Delaunay. Para el grabado de la página 187, una triple arcada decorada con atauriques, que titulan: Porte de la Sala de Justicia, hemos encontrado dos fotografías, una de Louis de Clercq y otra de Masson que la recuerdan bastante.

${ }^{14}$ Estos dos ejemplos de Mauzaisse proceden de comunicación personal de Carlos Sánchez y Javier Piñar. 
El grabado de la página 179 nos muestra el Patio de los Leones tras las columnas de uno de los templetes que lo encuadran. De esta perspectiva disponemos de muchas fotografías de diferentes autores que pudieron haber sido usadas para el dibujo, entre ellas hemos seleccionado una de la colección que hiciera Robert P. Napper para Francis Frith y otra de la colección estereoscópica de Luis Leon Masson. En ambos casos el dibujante habría realizado algunos retoques.

\subsection{Coincidencias con grabados de otros autores}

Para finalizar mencionaremos algunas coincidencias con grabados de una publicación anterior. Cuando examinamos los grabados uno por uno para realizar el estudio y seleccionar o descartar aquellos que pudieran estar relacionados con fotografías, nos llamó la atención una imagen que reproduce la puerta del Perdón de la catedral de Sevilla y a su izquierda, sobresaliendo por encima, la torre de la Giralda. Esta puerta está situada en la antigua calle Alemanes y frente a ella, aún hoy, existen unos edificios con soportales sujetos por columnas, de tal manera que por mucho que nos alejemos para realizar una toma fotográfica resulta imposible captar en su totalidad la imagen que hemos descrito, así que en principio este grabado quedó descartado. Sin embargo, la imagen nos resultaba tan familiar que la buscamos entre los grabados de otras publicaciones de la época hasta que por fin la encontramos (Bégin, 1852, p. 450). Las dos imágenes son tan parecidas que no puede caber duda alguna sobre el hecho de que la de Doré está prácticamente calcada de la realizada por los hermanos Rouargue para el libro de Bégin15. A Doré debió gustarle el encuadre y no disponiendo de dibujos propios ni fotografías que lo recogiesen decidió copiarlo. Este hecho nos sorprendió mucho pero también nos animó a repasar el libro de Bégin y acabamos encontrando otros dos grabados, de Sevilla y Córdoba, que pudieron haber sido utilizados por Doré. En el Cuadro 1 dejamos detalle de ello. Se trata de la puerta del Perdón y la Giralda sevillana, hemos encontrado grandes similitudes entre el $n^{0} 311$ de Doré (interior de la catedral de Sevilla)

\footnotetext{
15 David Roberts hizo un dibujo muy similar que posiblemente sea el origen de los posteriores. Ver en: Roscoe (1836, p. 135).
} 
y el 458 de Bégin, y los números 447 y 442 respectivamente de Doré y Bégin, con una imagen del interior de la mezquita de Córdoba.
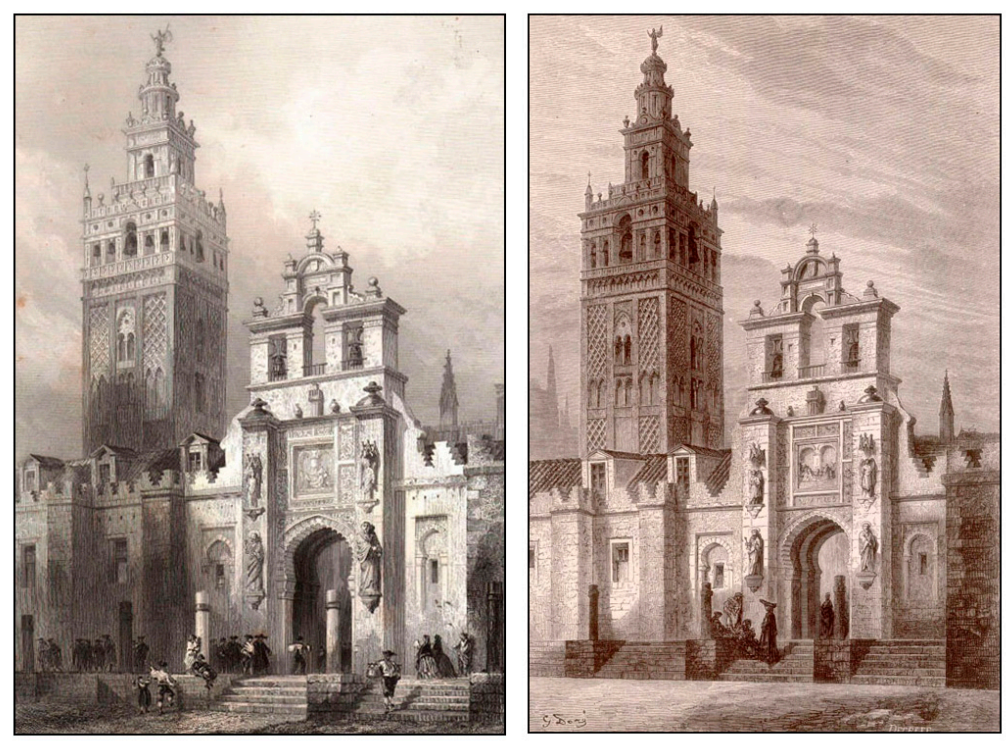

F8. Comparación de los grabados de los hermanos Rouargue para Voyage pittoresque en Espagne et en Portugal, y de Doré para L'Espagne.

\subsection{Posibles grabados de inspiración fotográfica, por constatar}

En el Cuadro 2 (Anexo 2) hemos recopilado aquellos grabados que en base a nuestra experiencia estudiando fotografías españolas de la época, consideramos que podrían haber tenido un origen fotográfico, aunque aún no podamos documentarlo. Las ciudades y temáticas aquí seleccionadas cumplen con nuestros requisitos de resultar "fotográficas" y tratarse de lugares incluidos en el circuito de los fotógrafos de la época, no obstante tenemos grabados de Jerez de la Frontera, Ronda, Itálica, Cuenca, Salamanca o Guadalajara, que son sitios poco frecuentes en los repertorios de los fotógrafos de aquellos momentos. En cambio, ciudades como Granada, Sevilla o Toledo fueron ampliamente fotografiadas por lo que no podemos descartar el futuro hallazgo de alguna fotografía que podamos relacionar con grabados de este grupo, cuando dispongamos de mejores fuentes documentales con imágenes. En especial de los siguientes grabados (siempre refiriéndonos al número de página del libro L'Espagne en el que figuran): $\mathrm{n}^{\circ} 315$ (puerta en la catedral de Sevilla), ${ }^{\circ} 275$ (Peñón de Gibraltar), no 319 (triple arcada en el Alcázar de Sevilla), no 439 (exterior de la mezquita de Córdoba), nº 555 (fuente de San Antonio en Aranjuez), nº 717 (patio del 
palacio del Infantado en Guadalajara) y $\mathrm{n}^{\mathrm{o}} 721$ (Torre Nueva, o inclinada, en Zaragoza).

\section{Conclusiones}

Para la confección de un buen número de los grabados aparecidos en la revista Le Tour du Monde y posteriormente en el libro L'Espagne, Gustave Doré utilizó fotografías como fuente de los dibujos previos. Ello resulta sorprendente por dos motivos. Por un lado, porque una de las características más notables del trabajo del autor era su desbordada imaginación, su alejamiento del realismo, cualidades por las que fue duramente criticado en su época, sabemos incluso que en Londres se hizo acompañar de dos dibujantes para que tomaran apuntes de la arquitectura, por lo que podemos intuir una cierta aversión a estas tareas. Y por otro lado también nos resulta extraño por la casi ausencia de esta práctica en el resto de la obra del autor. Efectivamente, en toda la bibliografía consultada sobre Doré solo hemos encontrado las dos leves referencias que hemos dejado anotadas procedentes de la biografía de Jerrold cuando habla del libro de Taine sobre el viaje a los Pirineos. Se trata de una alusión clara al uso de la fotografía para la confección de los grabados presentes en ese libro, por ello nos resulta un tanto inesperado no encontrar nuevas referencias sobre este asunto en el resto de la bibliografía, antigua o moderna, sobre la obra del autor, máxime cuando esta biografía fue publicada en 1891. La causa puede estar en que efectivamente no han podido hallarse pruebas o rastros del uso de fotografías por parte de Doré para otros trabajos, por lo que podemos concluir que en el caso del nuestro estamos ante un libro singular que contiene un número considerable de grabados (al menos el 12\% del total), que han sido dibujados de forma indudable a partir de fotografías y en total unos 66 grabados (más del 20\% del total) que son bastante "topográficos" y que calificamos como sospechosos de haber sido influenciados también por fotografías aunque aún no hayamos podido identificarlas con total claridad.

El estudio en detalle de las fotografías y sus autores en relación con cada uno de los grabados con los que se relaciona ha constituido el núcleo central de 
este trabajo. Quedaría para otra ocasión la elaboración de alguna hipótesis que pudiera explicar este proceder en un autor como Doré. Por nuestra parte señalaremos que la idea de Doré al venir a España no fue nunca la de preparar un libro con grabados del país sino la de inspirarse para la próxima publicación de su libro sobre El Quijote en el que tenía puestas grandes esperanzas e ilusiones. Como forma de sufragar el viaje la revista Le Tour $d u$ Monde iría publicando entregas sobre los lugares visitados. Visto así quizás para el artista se trataba de un trabajo menor en el que no le importó ceder a las presiones o sugerencias del editor para que entre los grabados no faltaran los grandes monumentos españoles que el lector esperaba encontrar y Doré acudió a la fotografía para ese tipo de dibujos.

\section{Referencias bibliográficas}

Alonso Martínez, F. (1999). "Recuerdos y Bellezas de España” y su relacióncon el medio fotográfico. Archivo español de arte, 72 (286), 192-198.

http://archivoespañoldearte.revistas.csic.es/index.php/aea/article/vie $\mathrm{w} / 756 / 771$ DOI 10.3989/aearte.1999.v72.i286.756

Bégin, Émile. (1852). Voyage pittoresque en Espagne et en Portugal. París:Belin-Leprieur et Morizot.

Casado Cimiano, P. (2013). Biografía Gustave Doré (1832-1883). En Doré y las Fábulas de la Fontaine en la Colección UC de Arte Gráfico. Cantabria: Universidad de Cantabria.

Davillier, Ch. (1874). L'Espagne, illustrée de 309 gravures dessinées sur bois par Gustave Doré. París: Librairie Hachette et $\mathrm{C}^{\mathrm{a}}$.

Díaz Francés, M. (2016). J. Laurent 1816-1886, un fotógrafo entre el negocio y el arte. Madrid: Ministerio de Educación, Cultura y Deporte.

Fernández Rivero, J. A. (2004). Tres dimensiones en la historia de la fotografía. La imagen estereoscópica. Málaga: Editorial Miramar.

Fernández Rivero, J. A. (2011). Los fotógrafos Lamy y Andrieu. En Una imagen de España. Fotógrafos estereoscopistas franceses (18561867). Madrid: Fundación Mapfre.

Fernández Rivero, J.A. \& García Ballesteros, M.T. (2017). Descubriendo a Luis Masson, fotógrafo en la España del XIX. Málaga: Ediciones del Genal.

Fontanella, L. (1999). Clifford en España. Un fotógrafo en la corte de Isabel II. Madrid: El Viso. 
Foulché-Delbosc, R. (1896). Bibliographie des voyages en Espagne et Portugal. París: H. Welter.

Hamerton, Ph. G. (1864). Gustave Doré, The Fine Arts Quarterly Review, oct, pp. 4-5.

Jerrold, B. (1891). Life of Gustave Doré. London: W. H. Allen \& Co. Ltd.

Kaenel, P. (2012). Gustave Doré à l'ouvre: vision photographique, imitation et originalité. Textimage, octobre, 1-17. https://revuetextimage.com/conferencier/o1_image_repetee/kaenel.pdf

Lerebours, N. (1840-1844). Excursions Daguerriennes, représentant les vues et les monuments les plus remarquables du globe. París.

Montes Ruiz, R. (1999). Córdoba en la segunda mitad del siglo XIX, a través de las fotografías de J. Laurent. En La Andalucía del siglo XIX en las fotografias de J. Laurent y $C^{a}$. Almería: Junta de Andalucía.

Piñar Samos, J, \& Sánchez Gómez, C. (2013). Luz sobre papel. La imagen de Granada y la Alhambra en las fotografías de J. Laurent. $2^{\mathrm{a}}$ ed. Granada: TF/Patronato de la Alhambra.

Riego, B. (2001). La construcción social de la realidad a través de la fotografía y el grabado informativo en la España del siglo XIX. Santander: Universidad de Cantabria.

Roscoe, T. (1836). The Tourist in Spain. Andalusia. Londres: Robert Jennings \& Co.

Sazatornil Ruiz, L. (2011). El Barón Davillier: Hispanista, anticuario y viajero por España. En Cabañas, M. El Arte y el Viaje. Madrid: Instituto de Historia.

Sazatornil Ruiz, L. (2016). El Voyage en Espagne de Gustave Doré y el Barón de Davillier. En El viaje por España de G. Doré en la Colección UC de Arte Gráfico. Santander: Universidad de Cantabria.

Sougez, M. (1985). Historia de la fotografía. Madrid: Cátedra.

Sougez, M. (1989). La imagen fotográfica en el medio impreso. Desarrollo de la fotomecánica y aproximación a los inicios en España. En Kurtz, G. \&Ortega, I. 150 años de fotografía en la Biblioteca Nacional. Madrid: Ministerio de Cultura.

Taine, H. A. (1855). Voyage aux eaux des Pyrénées. Paris. L. Hachette et Cie.

Levenfeld, R. [Comisario] (2014). El mundo al revés. El calotipo en España. Pamplona: Museo Universidad de Navarra.

Zola, E. (1892). Mis odios. Madrid: La España Moderna. 


\section{ANEXO 1}

CUADRO 1 - Gustave Doré - Grabados y fotografias relacionadas

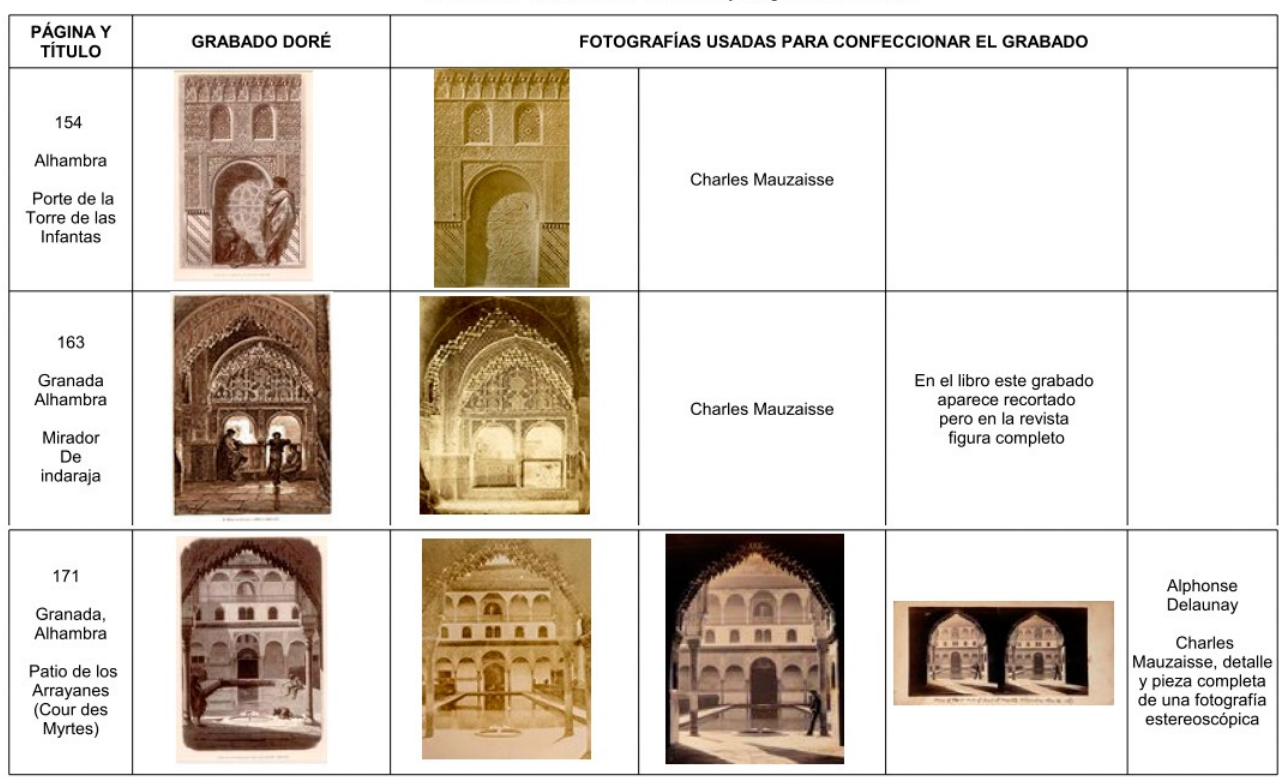

Página

CUADRO 1 - Gustave Doré - Grabados y fotografias relacionadas

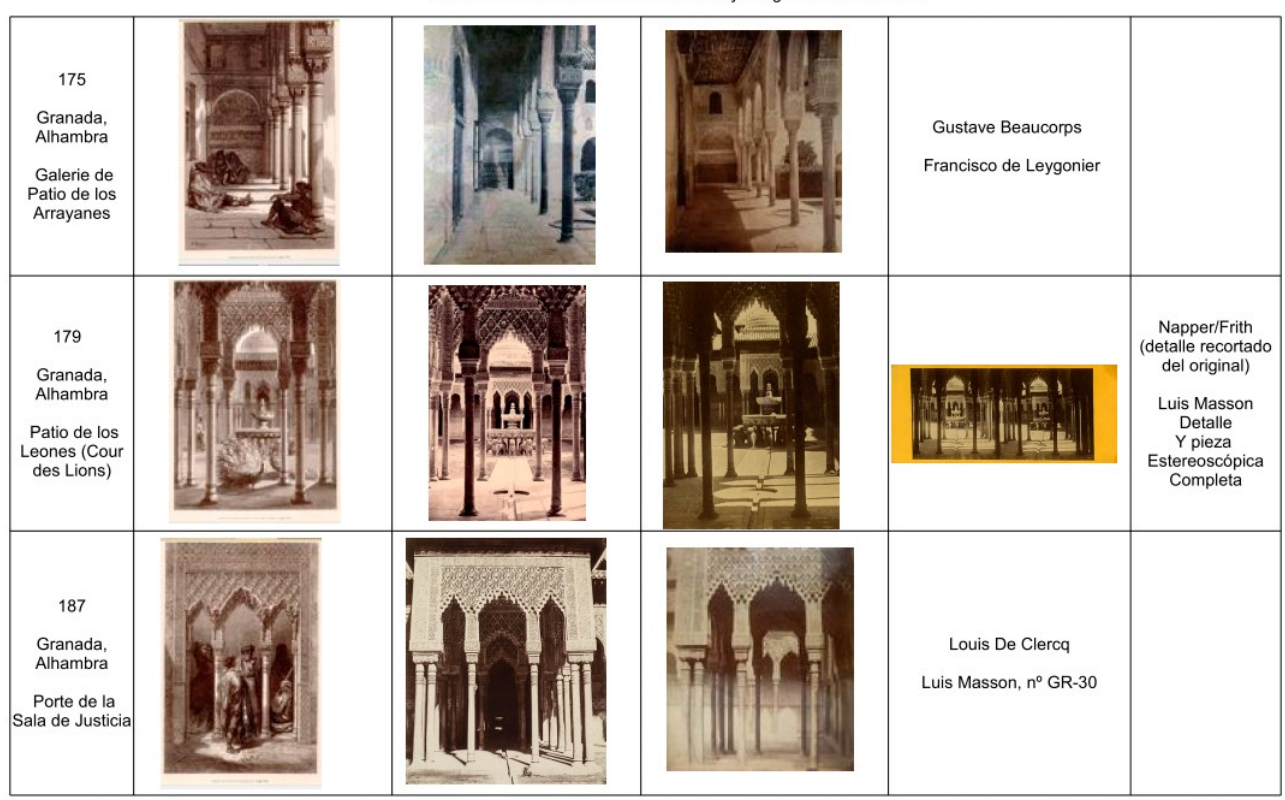

Página 2 


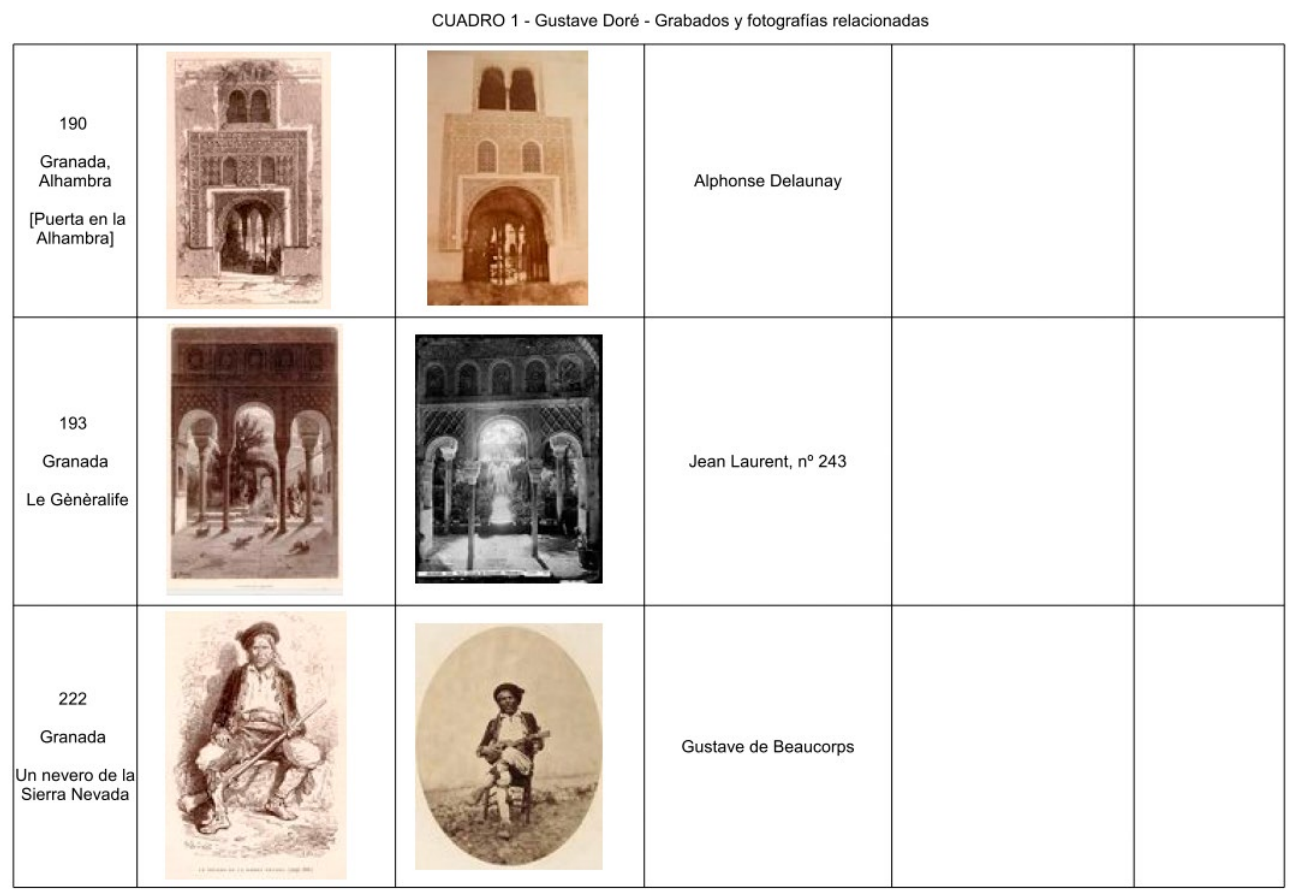

Página 3

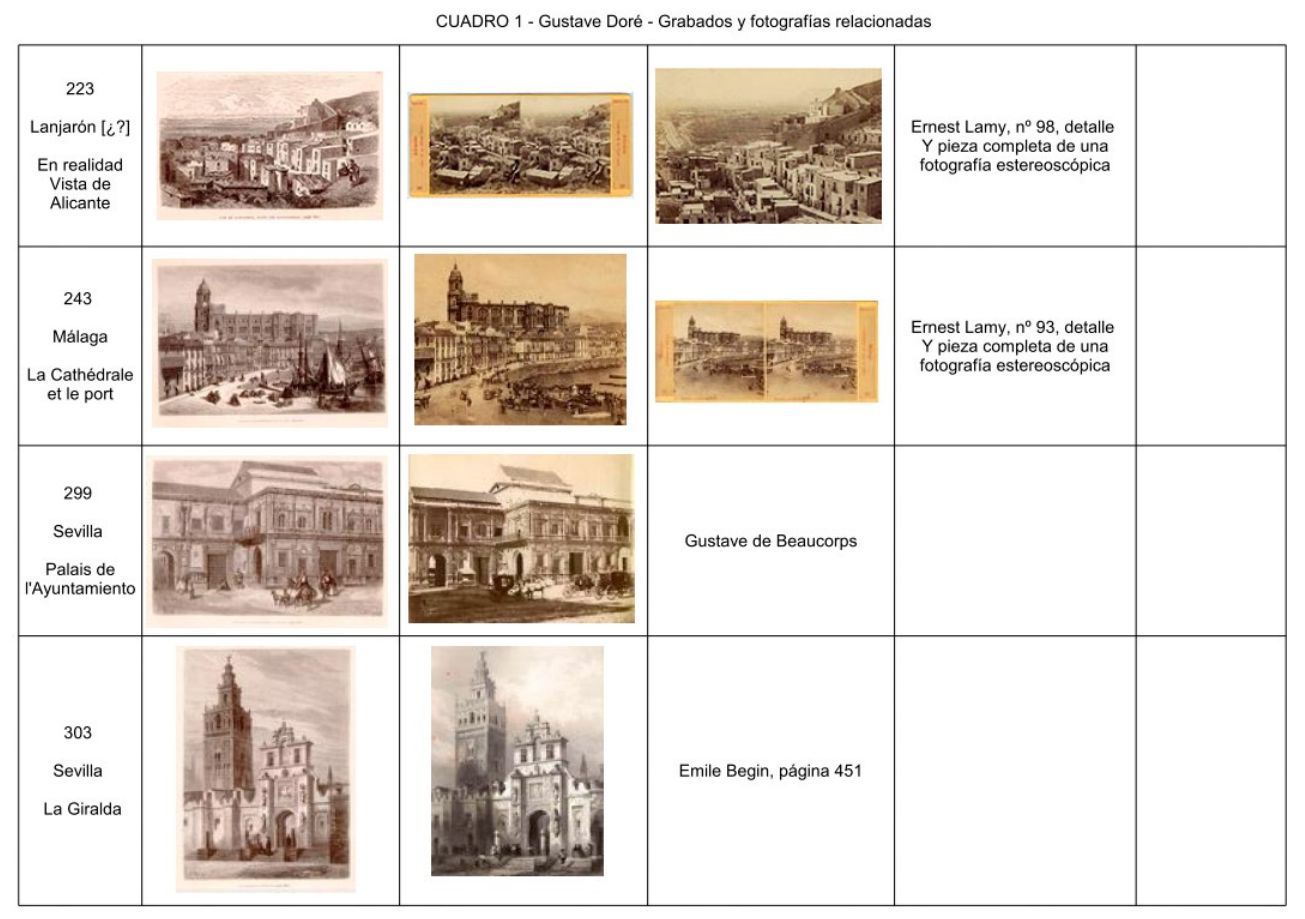

Página 4 
CUADRO 1 - Gustave Doré - Grabados y fotografias relacionadas

\begin{tabular}{|c|c|c|c|c|c|c|}
\hline $\begin{array}{c}\text { Sevilla } \\
\text { Puerta del } \\
\text { Perdon, a la } \\
\text { Cathédrale de } \\
\text { Séville }\end{array}$ \\
\hline $\begin{array}{c}\text { Sevilla } \\
\text { Interieur de la } \\
\text { Cathédrale }\end{array}$ \\
\hline $\begin{array}{c}311 \\
\text { Sevilla } \\
\text { Façade de } \\
\text { I'Alcazar }\end{array}$
\end{tabular}

Página 5

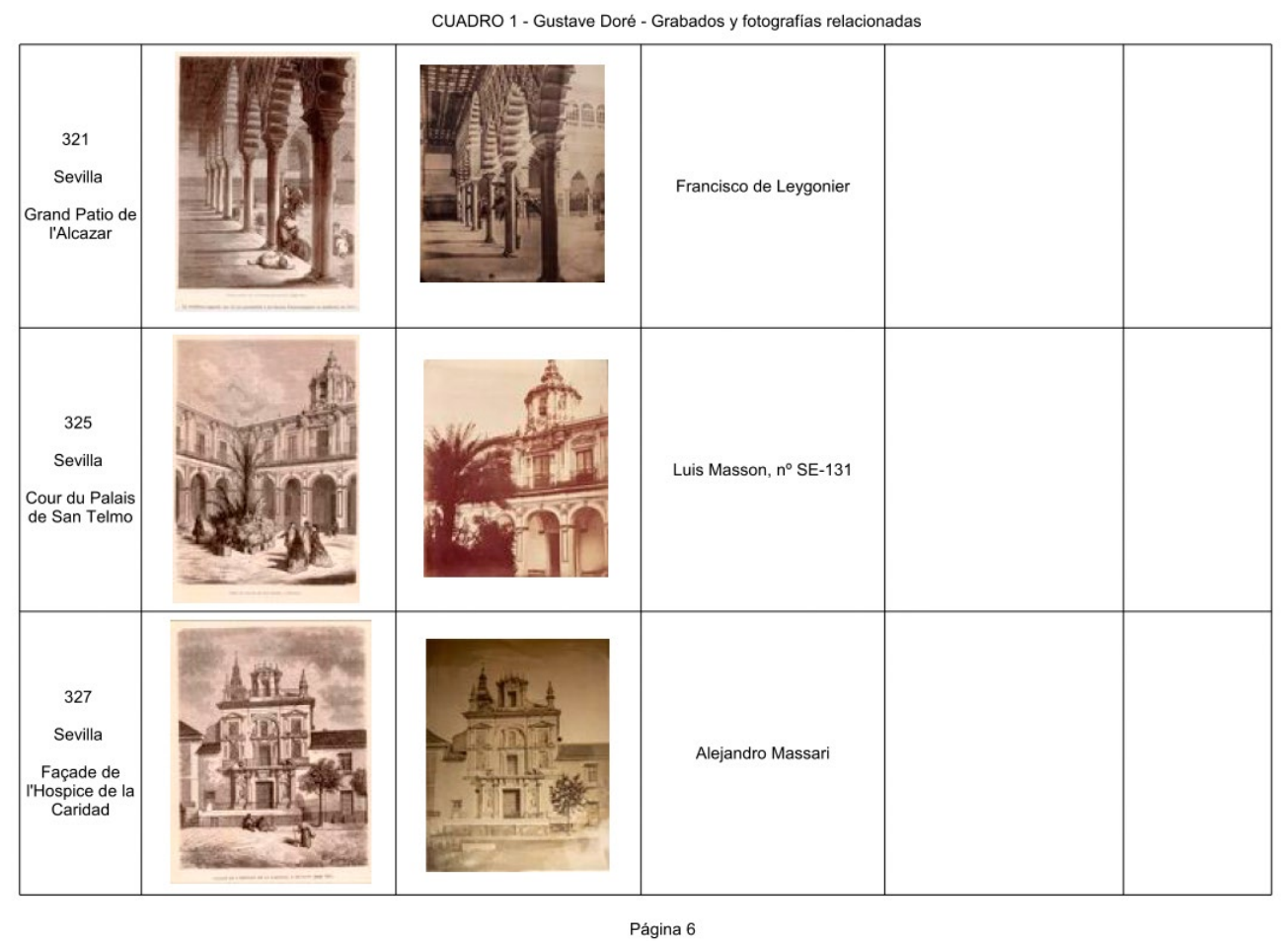


CUADRO 1 - Gustave Doré - Grabados y fotografias relacionadas

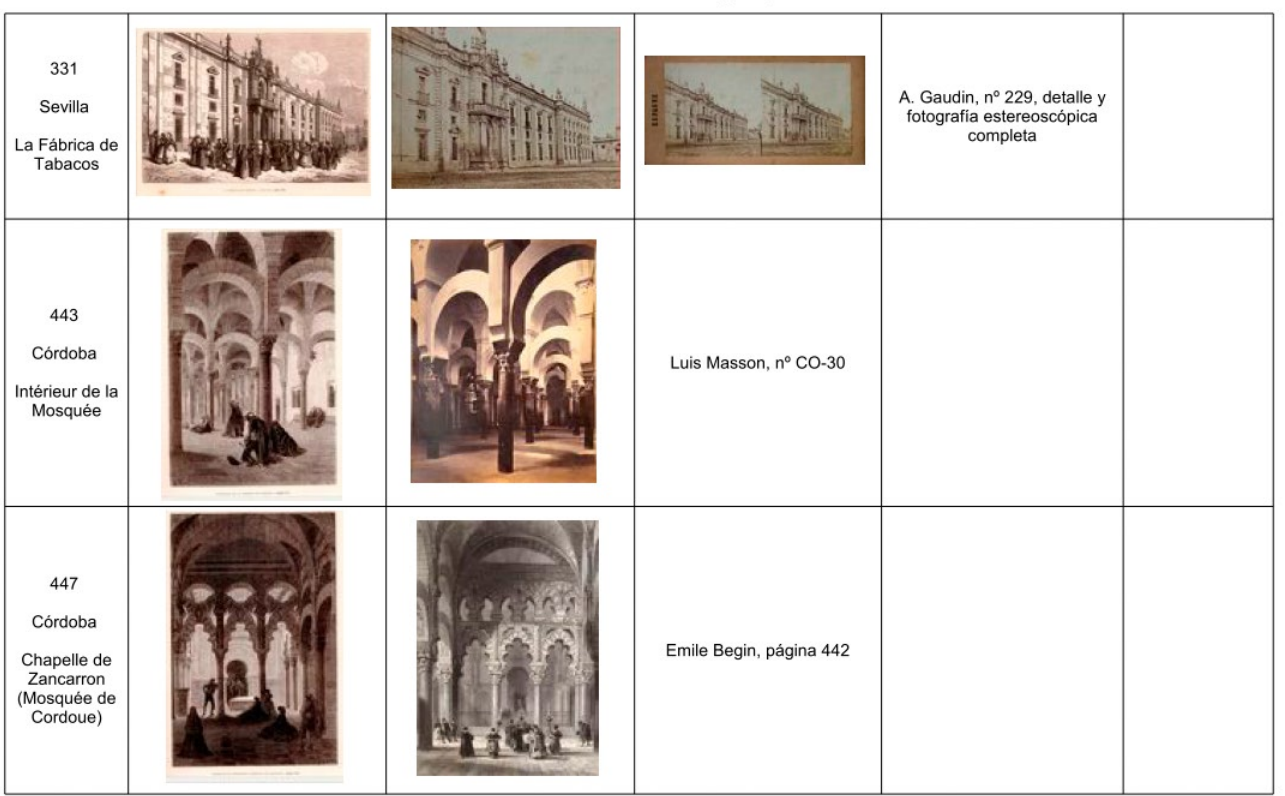

Página 7

CUADRO 1 - Gustave Doré - Grabados y fotografias relacionadas

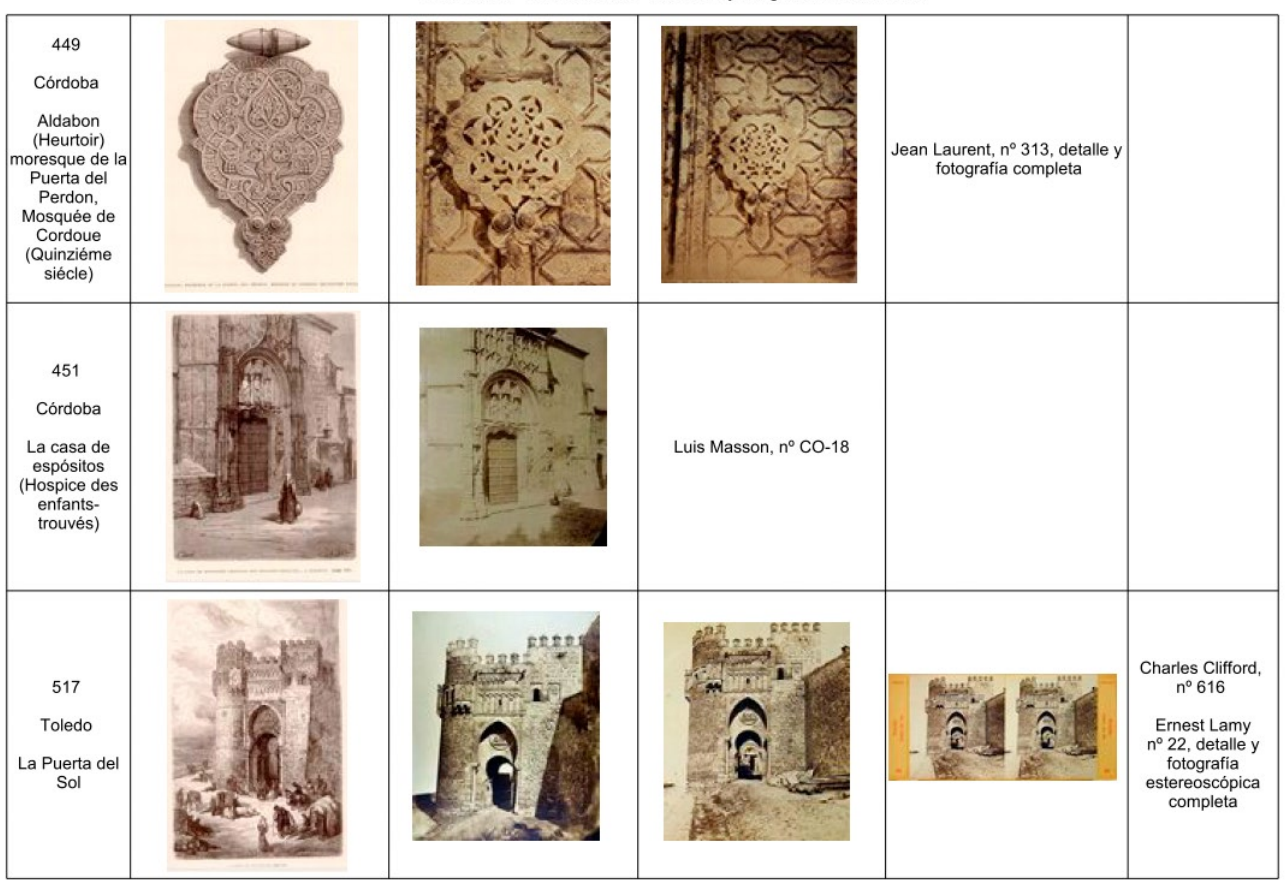

Página 8 


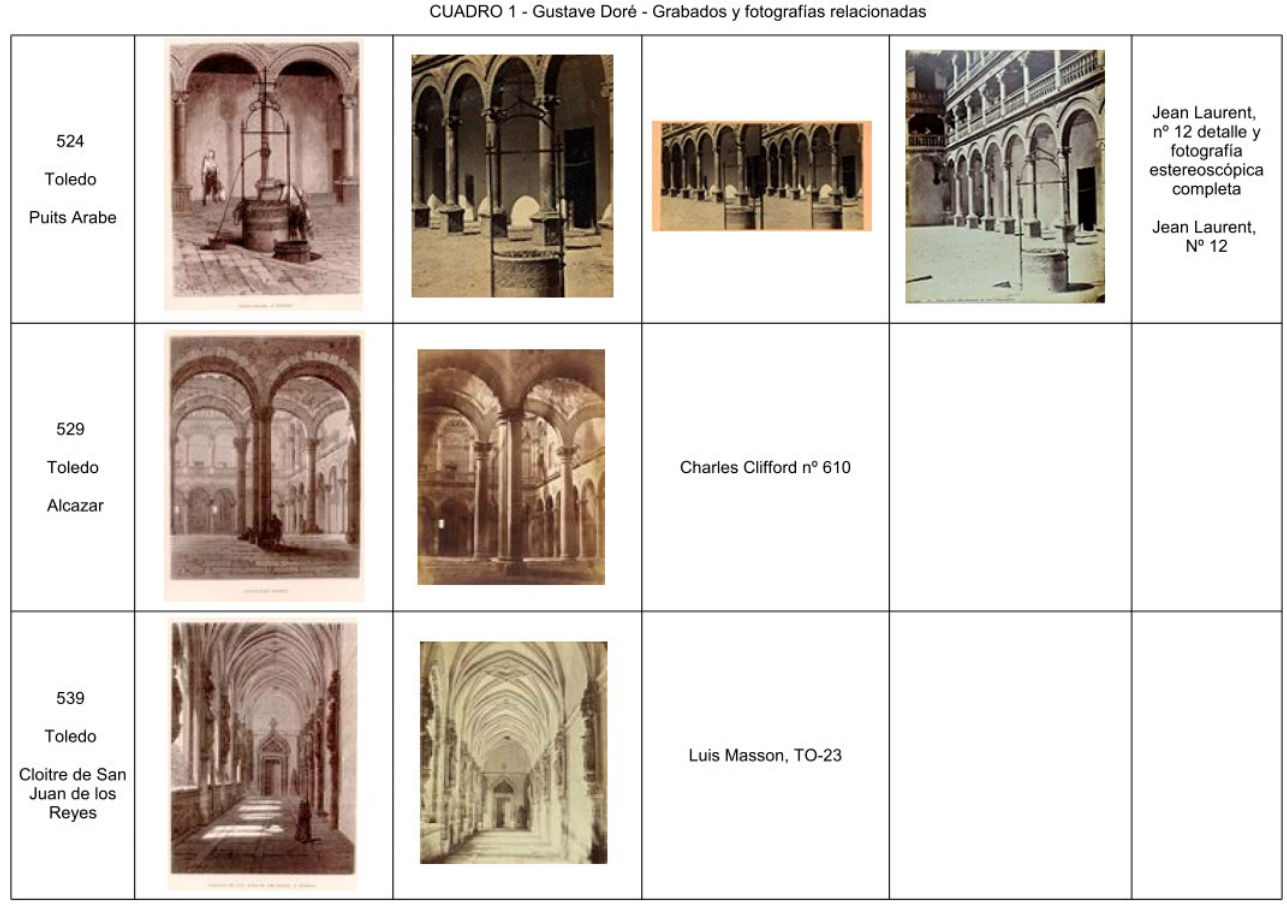

Página 9

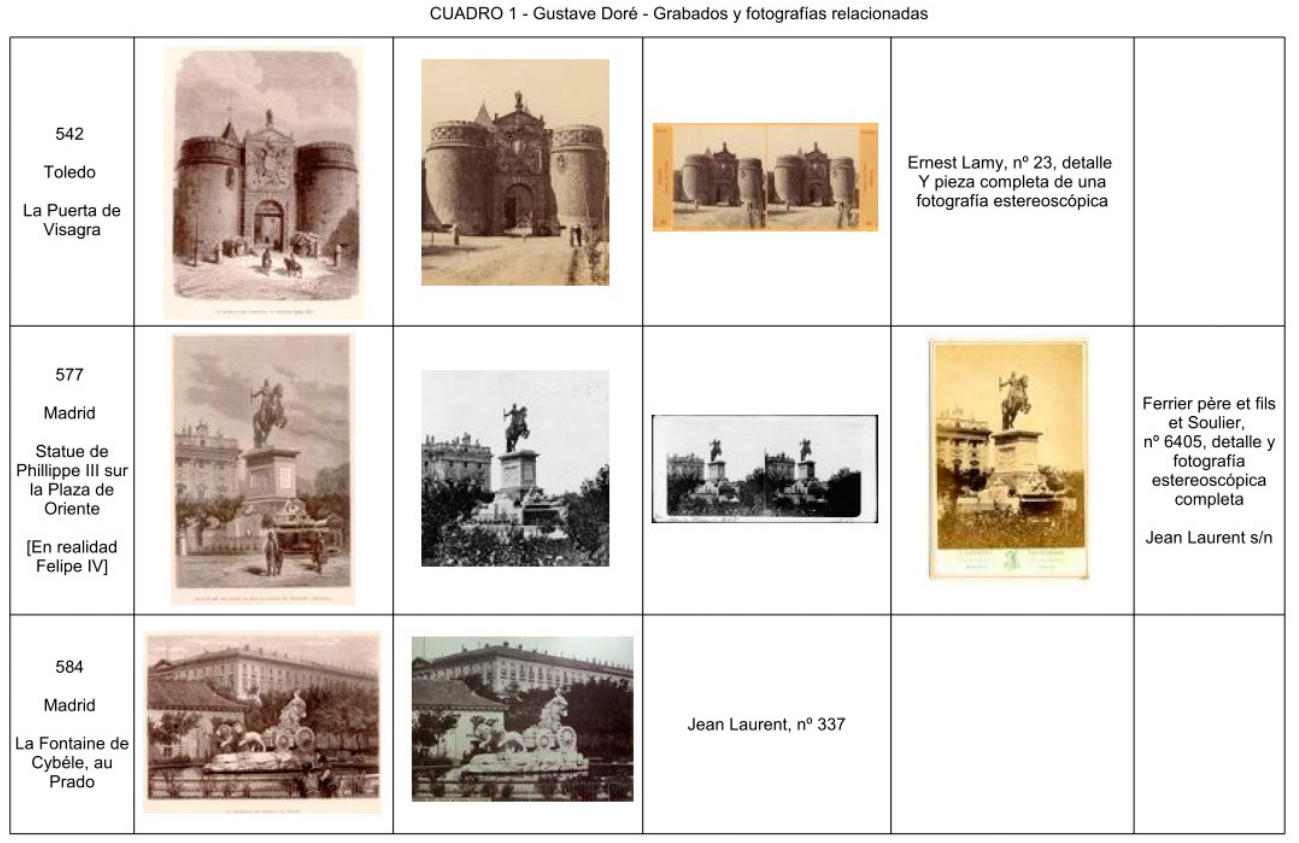

Página 10 


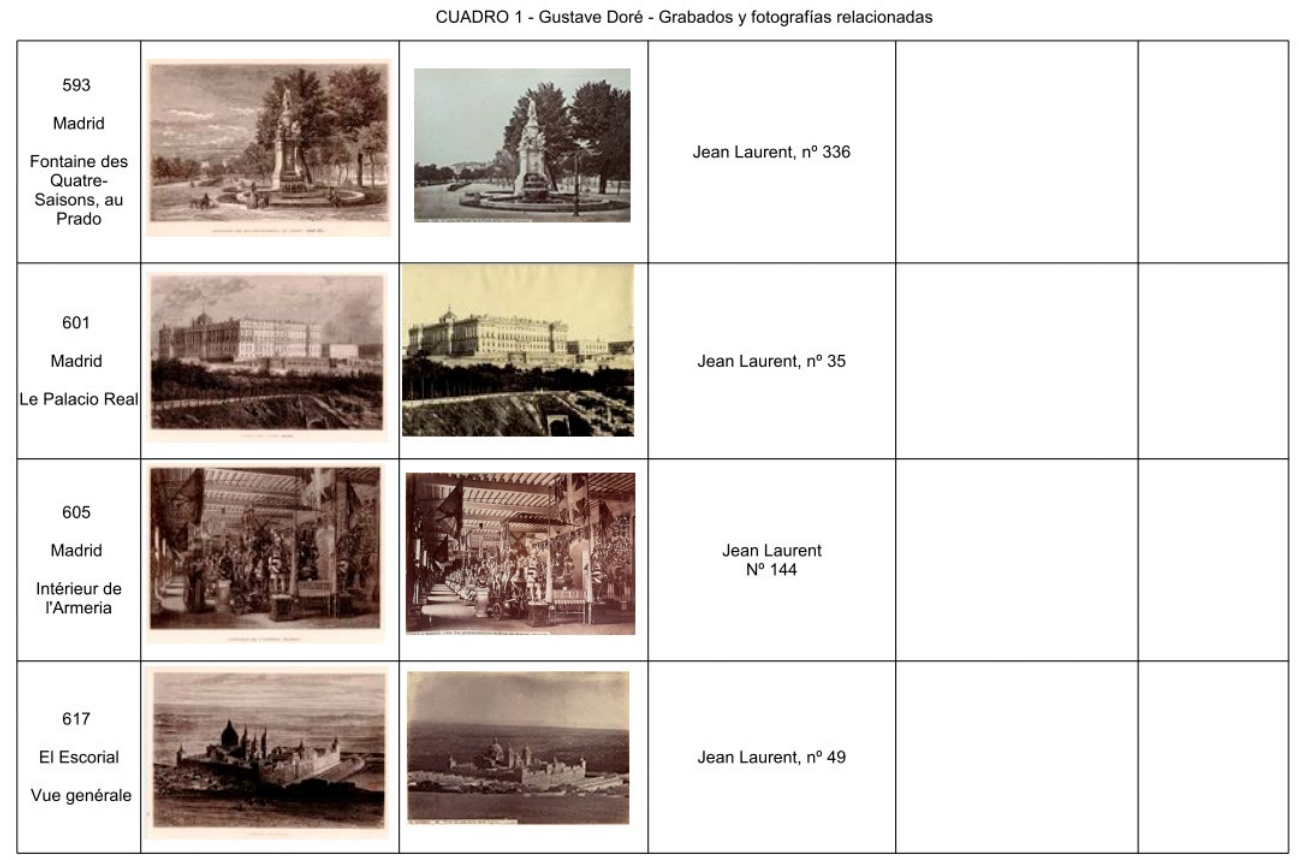

Página 11

CUADRO 1 - Gustave Doré - Grabados y fotografias relacionadas

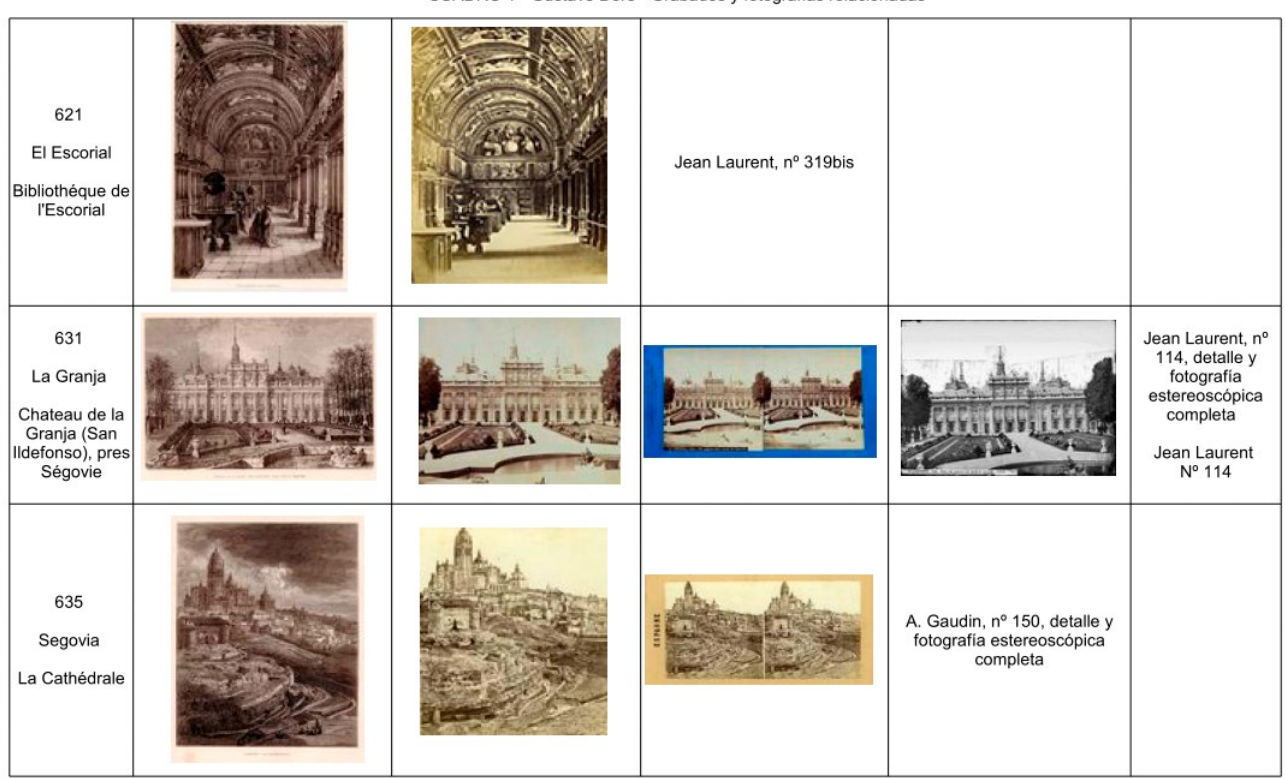

Página 12 


\section{ANEXO 2}

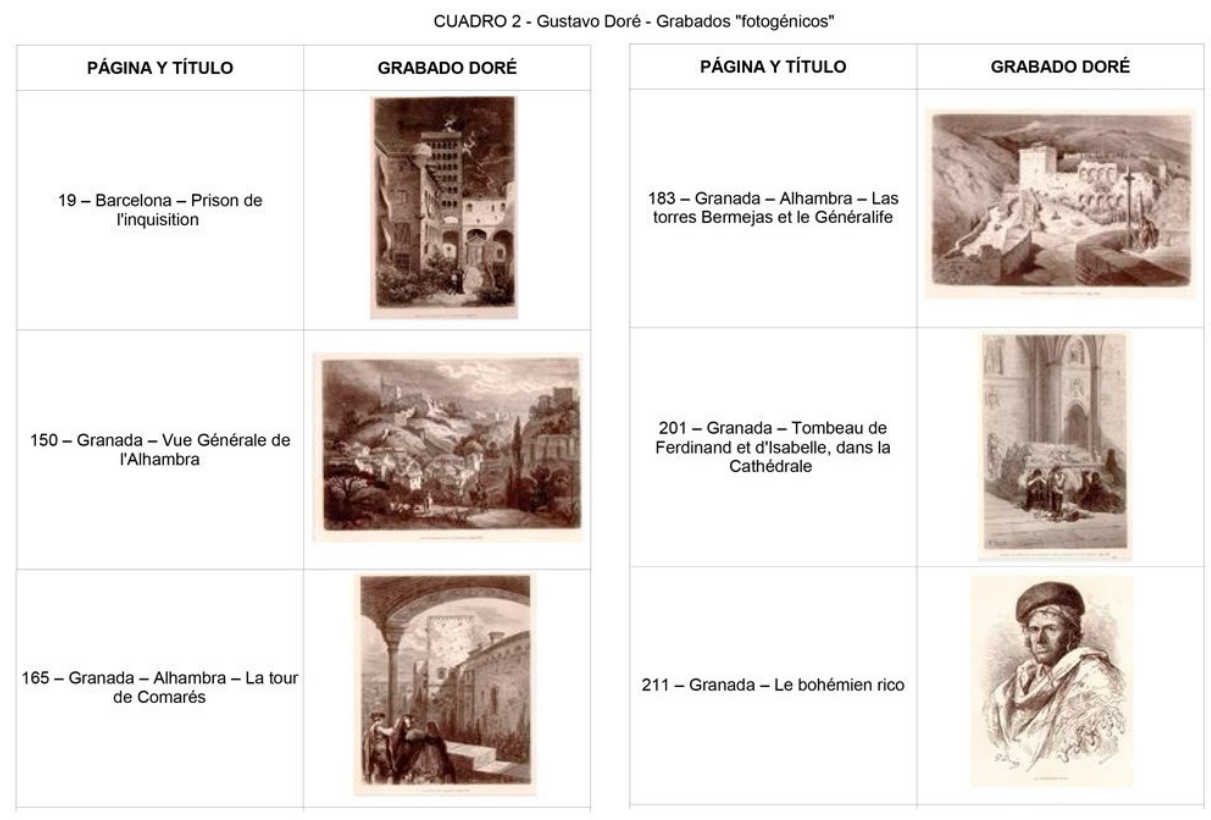

Pagina 1

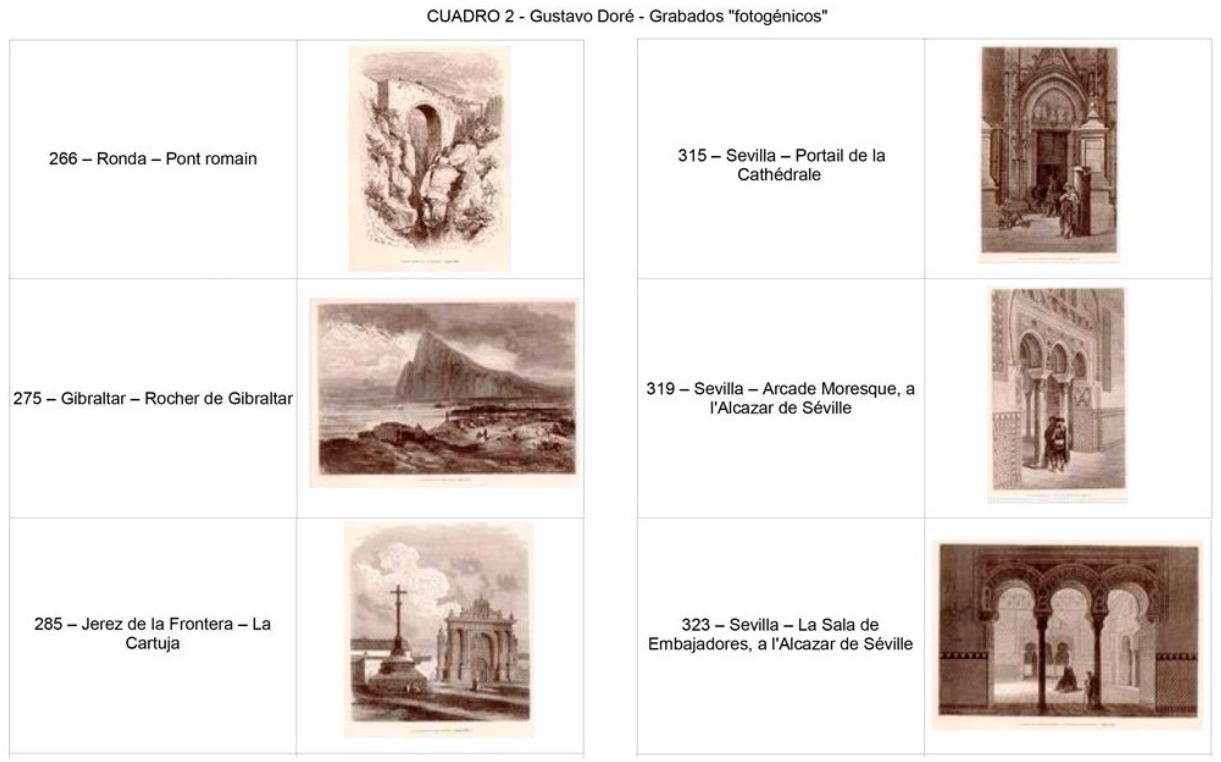

Página 2 


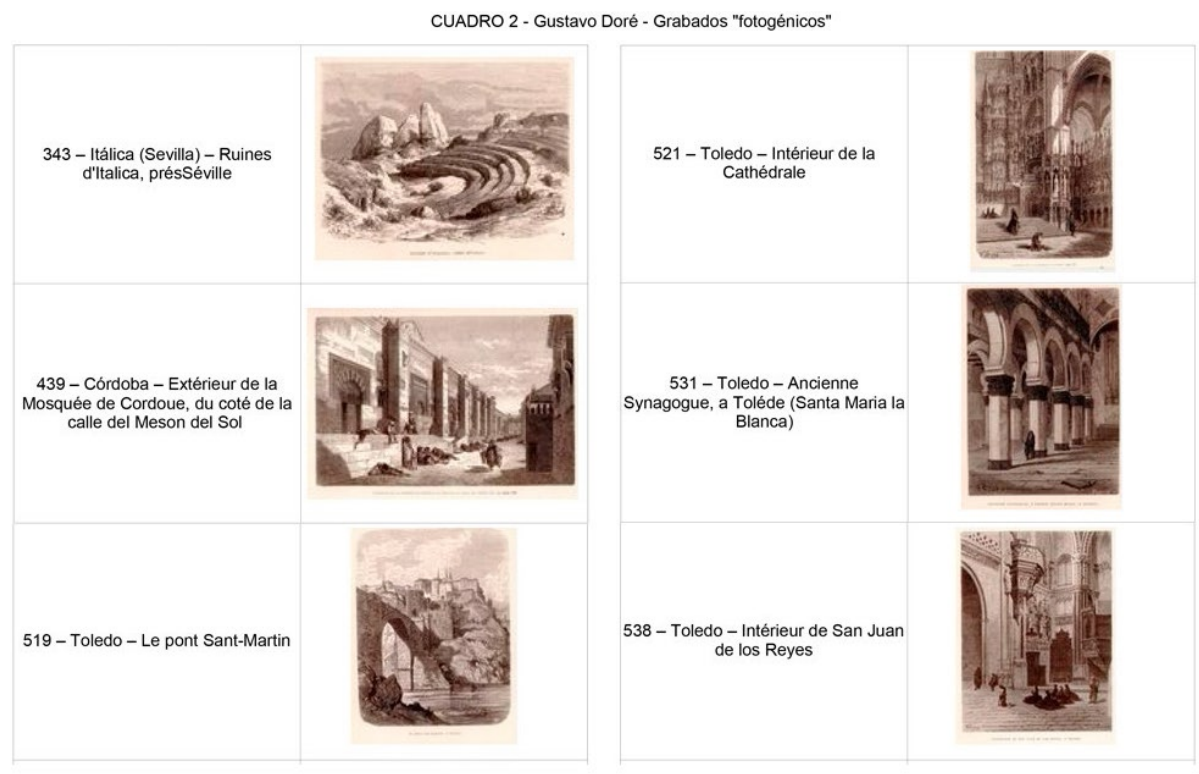

Pagina 3

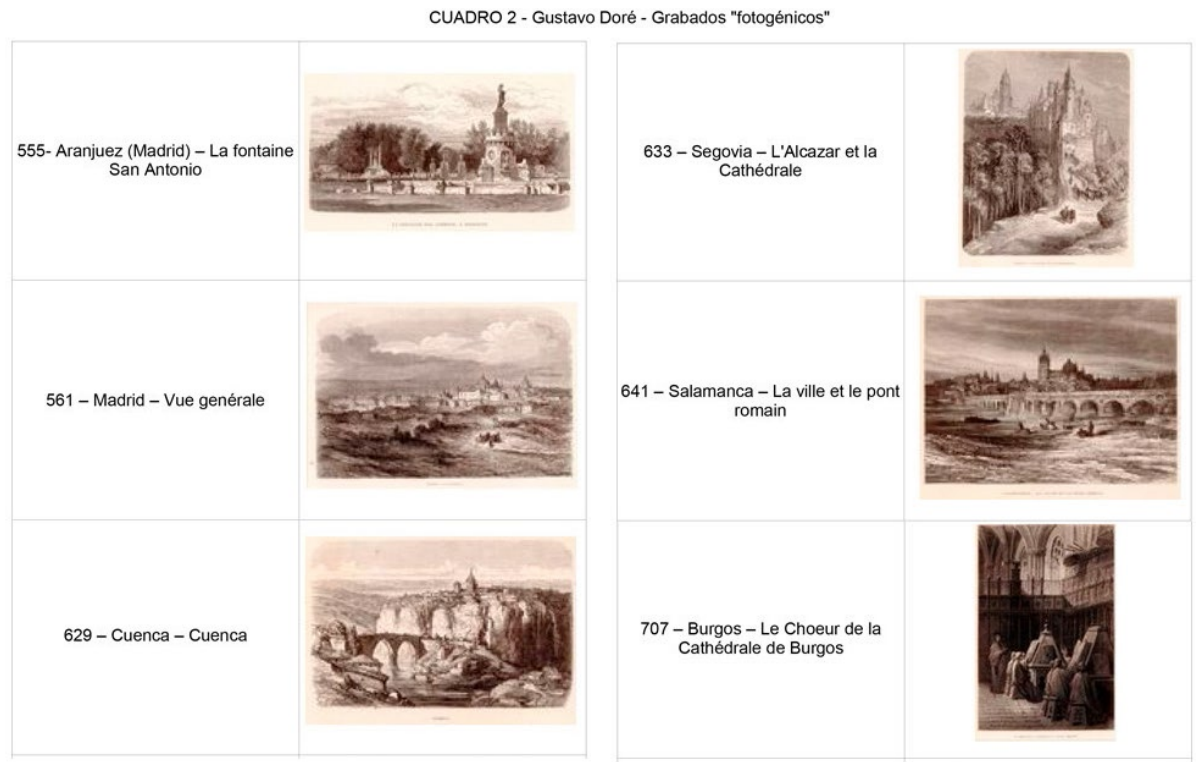

Pagina 4 
CUADRO 2 - Gustavo Doré - Grabados "fotogénicos"

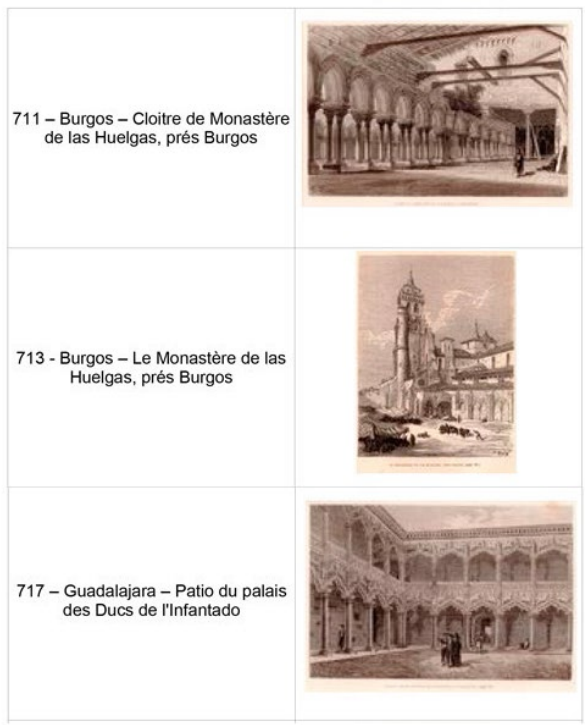
721 - Zaragoza - Tour penchée
(Torre Nueva)

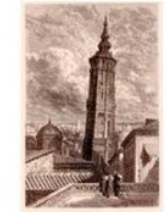

749 - Madrid - Ouclier dit a la

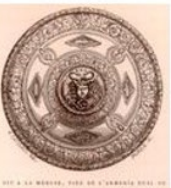
Méduse, tiré de l'Amería Real

Página 5 